ARTIGOS 


\title{
MELQUISEDEC NO JUDAÍSMO E NO CRISTIANISMO E SEU SIGNIFICADO NA DISPUTA ENTRE REGNUM E SACERDOTIUM NA IDADE MÉDIA
}

\author{
Nachman Falbel \\ Departamento de História, Faculdade de Filosofia, Letras e \\ Ciências Humanas, Universidade de São Paulo
}

\begin{abstract}
Resumo
Este estudo visa elucidar a contínua presença histórica da singular figura bíblica de Melquisedec que se prestou a múltiplas interpretações no pensamento religioso judaico e cristão. Desde o primeiro século de nossa era, a imagem de Melquisedec faria dele um símbolo central nas disputas teológicas entre as duas religiões assim como em várias seitas marginais que delas se originaram. Mais tarde, durante o período medieval, darse-ia um notável desdobramento do conceito de rex-sacerdos tendo um papel relevante no pensamento político e nas controvérsias entre o poder temporal e espiritual, entre regnum e sacerdotium.
\end{abstract}

Pallavras-chave

Melquisedec $•$ Bíblia $\bullet$ judaísmo $\bullet$ cristianismo $\bullet$ regnum $\bullet$ sacerdotium .

\section{Contato:}

Departamento de História - FFLCH/USP

Av. Professor Lineu Prestes, 338

Cidade Universitária - São Paulo - São Paulo

05508-900

E-mail:nfalbel@terra.com.br 


\title{
MELCHISEDEC IN JUDAISM AND CHRISTIANITY AND HIS SIGNIFICANCE IN THE CONTROVERSY BETWEEN REGNUM AND SACERDOTIUM IN THE MIDDLE AGES
}

\author{
Nachman Falbel \\ Departamento de História, Faculdade de Filosofia, Letras e \\ Ciências Humanas, Universidade de São Paulo
}

\begin{abstract}
This study aims to clarify the continuous historical presence of Melchisedec, the singular biblical figure which lend itself to a multiple interpretations within the Jewish and Christian religious thought. Since the first century of our era, the image of Melchisedec would turned him into a major symbol of the theological discussions between the two religions, as well as the others marginal sectes which were originated from both of them. Later on, throughout the Middle Ages, a remarkable development of the concept of rex-sacerdos would took place with a significant role in the political thought and the controversies between regnum and sacerdotium.
\end{abstract}

\section{Keywords}

Melchisedec $\bullet$ Bible $\bullet$ Judaism $\bullet$ Christianity $\bullet$ regnum $\bullet$ sacerdotium .

\section{Contact:}

Departamento de História - FFLCH/USP

Av. Professor Lineu Prestes, 338

Cidade Universitária - São Paulo - São Paulo

05508-900

E-mail: nfalbel@terra.com.br 
Melquisedec, rei de Salém, trouxe pão e vinho; ele era sacerdote do Deus Altíssimo; ele abençoou Abrão, dizendo: "Bendito seja Abrão pelo Deus Altíssimo; que criou o céu e a terra; e bendito seja o Deus Altíssimo que entregou teus adversários em tuas mãos!” E Abrão lhe deu o dízimo de tudo (Gn 14:18-20).

O autor da narrativa no livro do Gn 14:18-20, que se refere ao encontro de Abraão com o enigmático personagem denominado Melquisedec, nunca poderia imaginar que os poucos e intrigantes versos que escrevera poderiam atravessar os tempos instigando a imaginação humana e provocando as mais inusitadas interpretações. Desse modo, podemos endossar plenamente as palavras de um dos mais destacados historiadores de nosso tempo, Salo Baron, ao escrever: "The mysterious personality of the priest of Salem naturally struck imagination of the later teachers of the synagogue, church and mosque".

Estudiosos das Escrituras Sagradas, com os melhores instrumentos da crítica bíblica moderna, procuraram esclarecer a narrativa do capítulo 14 do Gênesis e o encontro entre Abraão e Melquisedec que, devido a vários aspectos de sua redação e da continuidade literária do texto do Pentateuco, a denominaram como "interlúdio Melquisedec", isto é, uma interrupção no fio que conduzia a "história dos reis". Sem pretendermos enveredar na questão sob o ângulo específico dos estudos bíblicos, que não é o escopo de nosso trabalho, limitamo-nos a algumas observações no que se refere aos dois versos. A própria expressão hebraica $E l$ Elyon (Deus Altíssimo) que designa a deidade foi submetida a uma intensa investigação, o que não nos garante que se chegou a uma opinião unânime sobre a mesma. Sob esse particular poderíamos esperar que as descobertas arqueológicas em Nuzi, Ugarit- Ras Shamra e outros sítios, que possibilitou um melhor conhecimento e deu um significativo aporte sobre o mundo bíblico assim como sobre as civilizações do Oriente Próximo, ainda não foi o suficiente para elucidar definitivamente a questão, ainda que tenham contribuído com uma informação que nos ajuda a especular sobre o seu significado histórico sob o ângulo religioso e político. O nome $E l$ era um apelativo semita para designar uma divindade assim como aparece associado a um local (El-Bethel, Gen 35:7) ou a um epíteto (El-Brith, “deus da aliança”, Juízes 9:46; El-Roi, Gen 16:13; cf. Gen 22:14), o que aponta originalmente para a existência de dois nomes divinos, El e Elyon,

1 BARON, Salo W. A social and religious history of the Jews. 2. ed. Nova Iorque-Londres-Filadélfia: Columbia University Press - The Jewish Publications Society of America, 1952, v. 1, p. 312. 
sendo o primeiro utilizado no culto de comunidades politeístas daquela região oriental. A lembrança na teogonia fenícia, de autoria de Philo Herennius de Byblos, na qual a deidade Eliun que, no grego, é explicado como Hypsistos, "altíssimo", aparece como o mais antigo deus, avô de Elos (El) e de seus irmãos, indica que são duas divindades diferentes. ${ }^{2}$ Salo Baron faz referência à descoberta de G. Levi della Vida em inscrições púnicas nas quais aparecem distintamente a denominação de $E l$ como deus da terra e Elyon como deus do céu, o que nos leva a lembrar a expressão das palavras no verso "que criou o céu e a terra" e a identificação que encontramos com Javé, indicando, ao mesmo tempo, ser El-Elyon identificado com os atributos "a divindade, o altíssimo". ${ }^{3}$ Mas esta associação com Javé, de acordo com Martin Rose, o autor do verbete "Names of God in OT" será fruto de um longo processo porque, ainda no Dt 32:8-9, Elyon é utilizado na acepção próxima à visão de mundo cananita, de um ser criador e sustentador que indica, às diferentes nações, uma porção habitável de terra e aponta a cada uma delas um ser divino, um deus $(E l)$. Nessa passagem, Javé adquiriu "seu povo bem como sua porção", o que, nesse caso, ainda pressupõe uma antiga diferenciação de um deus-criador supranacional (Elyon) e o deus nacional (Javé) assim como é apresentado no S1 82:1,6. Em várias passagens da Bíblia hebraica, os dois termos aparecem no mesmo versículo, porém separados por um paralelismo dual como podemos ver em S1 73:11 e 107:11. Melquisedec é rei de Salem, identificada com Jerusalém, tal como é indicado pelo salmo 76:3, no qual também é denominada Sião, o que supõe ser plausível a ideia de que El Elyon seria difundido entre as tribos de Israel através dessa cidadeestado cananita. A conjectura é de que tal processo iniciar-se-ia com os benjamitas, situados ao norte de Jerusalém, tomando-se como ponto de apoio a palavra Elyon que aparece na benção à tribo de Benjamin (cf. Dt 33:12) e se ampliaria, após a conquista de Jerusalém por David, às demais tribos que comporiam o reino (2 Sm 23:1; cf. $1 \mathrm{Sm} \mathrm{2:10).}{ }^{5}$ Com a consolidação do reino durante o reinado de David e Salomão, o culto nacional e oficial associará o nome $E l$

2 Cf. ASTOUR, Michael C. Melchizedek. In: FREEDMAN, David Noel (ed.). The Anchor Bible Dictionary. Nova Iorque: Doubleday, 1992, v. 4, p. 684, no qual se menciona a existência da mesma dualidade numa fonte aramaica.

3 BARON, Salo W. A social and religious history of the Jews, op. cit., v. 1, p. 312.

4 ROSE, Martin. Names of God in the OT. In: FREEDMAN, David Noel (ed.). The Anchor Bible Dictionary, op. cit., v. 4, p. 1.004.

5 Sobre Jerusalém vide TALMON, Schmaryahu. The signification of Jerusalem in biblical thought. In: KUHNEL, B. (ed.). The real and ideal Jerusalem in Jewish, Christian and Islamic art, Jewish art. Jerusalém: Centre for Jewish Art, 1997/98, v. 23-24, p. 1-12. 
Elyon ao de Javé, divindade originária do período nômade e que agora se enriqueceria como deus da criação do universo e senhor, ou rei supremo das nações da terra. Processo semelhante ocorreria com outras tradições do período préisraelita que seriam incorporadas ao mundo espiritual hebraico bíblico. Mas Javé e Elyon se revelariam durante muito tempo nos paralelismos poéticos em 2 Sam 22:14, repetido em S1 18:14 e Ps 21:8 e enfatizado com a expressão "Javé-Elyon é terrível, e poderoso rei sobre toda a terra", no verso em S1 47:2. Se for correta a hipótese aceita por certos estudiosos de que o rei David, com a conquista de Jerusalém das mãos dos jebusitas, reivindicou a sucessão de Melquisedec para afirmar a hegemonia política do novo reino, ${ }^{6}$ poderíamos inferir que, desde o período bíblico, a misteriosa figura intimamente associada ao patriarca Abraão, que estabelecera a aliança entre Deus e seu povo, tinha, desde o início, múltiplos significados teológico-políticos que extrapolariam as fronteiras do judaísmo propriamente dito. Contudo, devemos observar que alguns estudiosos, apesar de concordarem com a existência de extratos antigos na narrativa bíblica, veriam sua elaboração final como fruto do período persa que permite a volta dos exilados, se incumbe da reconstrução do Templo de Jerusalém e afirma o poder espiritual do sacerdócio. Porém, o significado maior da famosa passagem em que Abrão (ainda não era Abraão) aparece, excepcionalmente, como guerreiro, e dá a Melquisedec o dízimo de tudo, é a afirmação de que o sacerdócio do Deus Altíssimo, criador do universo, já existia anteriormente em Jerusalém e que o sacerdote de El Elyon era também rei de Salem (ou Jerusalém cf. S1 76:3), ou seja, na figura de um rex-sacerdos. Quanto ao patriarca, que lutara e vencera a coligação dos reis sob a liderança de Quedorlaomer, acabaria por herdar os direitos sobre seus extensos territórios e pagaria o dízimo a Melquisedec reconhecendo, desse modo, a sua superioridade (Gn 14:1-17). Porém, devido à partícula pronominal hebraica (na expressão "vaiten-lo maaser"), alguns autores consideraram que não estava explícito quem pagou a quem o dízimo, detalhe gramatical que, mais tarde, seria utilizado como argumento na literatura polêmica judaico-cristã posterior. A outra menção de Melquisedec na Bíblia hebraica encontra-se no salmo 110:4 que reza: "Para sempre tu és sacerdote segundo a ordem (ou a maneira) de Melquisedec" e que celebra a elevação de um homem à dignidade de sacerdote, dominador, guerreiro, cujo nome poderia, hipoteticamente, ser desvendado através do acróstico nos versos 1-4 como sendo Simão, o que poderia indicar como sendo Simão Macabeu, um dos filhos de Matatias

$\overline{6}$ Cf. BARON, Salo W. A social and religious history of the Jews, op. cit., v. 1, p. 322. 
que liderou a revolta dos hasmoneus em 167 a. C. contra o domínio seleucida na Palestina. Simão, de fato, tornou-se sumo-sacerdote e comandante assumindo o governo dos judeus em 141 a. C. Nada mais intrigante do que essa interpretação sobre esse salmo do qual emana uma atmosfera heróica e que se utiliza em parte de expressões do salmo 2:7 e acentua a eternidade do sacerdócio "segundo a ordem de Melquisedec". Aqui, Melquisedec é figurado como sendo o sacerdote eterno de Javé e elevado à condição de um ser gerado pela divindade comparado à figura mitológica que aparece em Is 14:12 sob as palavras "estrela matutina, filho da aurora" (helel ben shachar). Desse modo, Simão Macabeu, ao assumir o sumo-sacerdócio, é identificado - certamente era o desejo do novo poder da família dos hasmoneus - como sucessor de Melquisedec. ${ }^{7}$ Porém, o autor do verbete "Melchizedek" na Encyclopaedia judaica ${ }^{8}$ lembra que certos autores não identificariam o Melquisedec do Gn 14:18-20 com o do salmo 110, alegando que o nome separado de Malki Tzedek - e assim ele aparece no versículo - indicaria um título e não uma pessoa. Joseph A. Fitzmyer aponta, em um artigo, o notável processo de alegorização que os versos do Gênesis sofreram através do tempo, o qual procura demonstrar, através das nuances nas traduções da Septuaginta e traduções posteriores como a Vetus Latina e a Peschitta, chamando a atenção, em especial, para as diversas leituras e o seu entendimento no período helenístico e romano e após que judeus e cristãos fizeram dos mesmos. ${ }^{9}$ Em todo caso, a maioria dos estudiosos concorda que o salmo 110:4 parece ser destinado ao coroamento dos reis israelitas e enfatiza o caráter religioso-sacerdotal da realeza hebraica no qual o rei-sacerdote de Salem-Jerusalém (no salmo 76: 2-3 Salem é identificada como Jerusalém: "Em Judá Deus é conhecido, em Israel grande é seu Nome; em Salem está o Tabernáculo, em Sião a sua Morada") se apresenta como modelo ideal. Do mesmo modo, na literatura rabínica, Salem será identificada com Jerusalém. Curiosamente, no Pseudo-Eupolemus, ao se referir ao encontro de Abraão, visto como uma figura extraordinária que ensinou astronomia e astrologia, primeiro aos fenícios e depois aos egípcios, Melquisedec é

7 Cf. ASTOUR, Michael C. Melchizedek. In: FREEDMAN, David Noel (ed.). The Anchor Bible Dictionary, op. cit., v. 4, p. 685. Consultar nota de rodapé em Is 14:12 na Bíblia da LEB-Ed. Loyola, 1983, p. 1.110.

8 GRUENWALD, Ithamar. Melchizedek. In: Encyclopaedia judaica. Jerusalém: Keter Publishing House, Fourth Printing, 1971-2, v. 11, p. 1288.

9 FITZMYER, Joseph A. Melchizedek in the MT, LXX, and the NT. Biblical studies on the web, v. 81, 2000, fascículo 1, p. 63-69. Disponível em: $<$ http://www.bsw.org/Biblica/Vol-81-2000/ Melchizedek-In-The-Mt-Lxx-And-The-Nt/278/> . Acesso em: 24 fev. 2010. 
descrito como rei e sacerdote do Templo de "Argarizin", significando Monte do Elevadíssimo. ${ }^{10}$

Melquisedec também terá um papel relevante na literatura de Qumran e um dos manuscritos, 11QMelch (11Q13), de caráter midrashico, o coloca como figura central, associado à interpretação do salmo 82:1-2 bem como do Is 14:12. O salmo em questão se refere à justiça do julgamento divino que, na escatologia de Qumran, finalizará com o triunfo do bem sobre o mal. Melquisedec será o juiz dos justos, dos fiéis a Deus, bem como dos seguidores e adeptos de Belial e suas hostes do mal, sendo assistido por divindades do bem que destruirá a Belial. À testa do conselho divino (a expressão hebraica no salmo 82:1-2 é "adat-el") que julgará as criaturas encontra-se Deus (Elohim) e seus auxiliares são os seres divinos (elohim). Os versos 2-3 do salmo interrogam "Até quando julgais injustamente, favorecendo a causa dos ímpios? Julgai em favor do fraco e do órfão; ao humilde, ao pobre, fazei justiça!", como que os acusando de negligenciar seu dever moral para com os homens, atuando injustamente e, desse modo, eles também merecerão castigo: "Eu disse: Vós sois deuses, todos vós sois filhos do Altíssimo (Elyon). Morrereis, no entanto, como os outros humanos, e tombareis igualmente como qualquer outro príncipe."

Melquisedec aparece como uma figura escatológica que julgará no tempo do décimo e último jubileu. Para conhecermos melhor seu conteúdo transcrevo na integra o texto de Qumran 11QMelch: Col.II 1[...] teu Deus...[...]2 [...]

E o que diz:

"neste ano de jubileu [voltareis cada qual à sua respectiva propriedade" (Lv.25:13), como está escrito: "Esta é] 3 a maneira (de fazer) [a remissão: todo credor fará remissão do que tiver emprestado [ao seu próximo. Não premerá o seu próximo nem o seu irmão quando se tiver proclamado] a remissão 4 para Deus (Dt 15:2). [Sua inter]pretação para os últimos dias se refere aos cativos, dos quais diz:

Para proclamar aos cativos a libertação (Is 61:1).” E fará prisioneiros 5 os seus rebeldes [...] e da herança de Melquisedec, pois [...] e eles são a heran[ça de Melqui]sedec, que 6 os fará retornar a eles. Ele proclamará para eles a libertação para libertá-los d[a dívida] de todas as suas iniquidades. E isto suce[dera] 7 na semana primeira do jubileu que segue os no[vê] jubileus. "E o dia [das expiaçõ]es é o final do jubileu décimo 8 no qual se expiará

${ }^{10}$ In: Encyclopaedia judaica, op. cit., vol. 6, p. 964-965. O Pseudo-Eupolemos é assim denominado devido à diferenciação entre esse fragmento, que se refere a Abraão, supostamente de influência samaritana, e os demais fragmentos de Eupolemos, o historiador grego-judeu que viveu no II século a. C., mencionados na Praeparatio evangélica de Eusébio e na Stromata de Clemente de Alexandria. V. SCHÜRER, Emil. A history of the Jewish people in the time of Jesus Christ. Nova Iorque: Charles Scribner's Sons, 1891, vol. V, p. 203-206. 
por todos os filhos de [Deus] e pelos homens do lote de Melquisedec. [E nas alturas] ele se pronun]ciará a eu] favor segundo os seus lotes; pois 9 é o tempo do "ano de graça" para Melquisedec, para exal[tar no pro]cesso os santos de Deus pelo domínio do juízo, como está escrito 10 sobre ele nos cânticos de Davi que diz: "Elohim se ergue na assem[bleia de Deus], em meio aos deuses julga" (S1 82:1). E sobre ele diz: "Sobre ela 11 retorna às alturas, Deus julgará os povos" (S1 7:7-8). E o que di[z: "Até quando jul]gareis injustamente e guardareis consideração aos malvados? Selah" (S1 82:2) 12 Sua interpretação concerne a Belial e aos espíritos de seu lote, que foram rebeldes [todos eles] apartando-se dos mandamentos de Deus [para cometer o mal.] 13 Porém Melquisedec executará a vingança dos juízos de Deus [nesse dia, e eles serão libertados das mãos] de Belial e das mãos de todos os es[píritos de seu lote.] (Is 61:3) 14 Em sua ajuda (virão todos "os deuses de [justiça"; ele é qu[em prevalecerá nesse dia sobre] todos os filhos de Deus, e ele pré[sidirá a assembleia] 15 esta. Este é o dia d[a paz do qual] falou [Deus desde antigamente pelas palavras de Isa]ias o profeta, que disse: "Que] belos são 16 sobre os montes os pés do proclamador que anuncia a paz, do pro[clamador do bem que anuncia a salvação,] dizendo a Sião: 'teu Deus [reina (Is 52:7) 17 Sua interpretação: Os montes são os profe[tas...] (Is 9:26) 18 E o proclamador é [o un]gido do espírito do qual falou $\mathrm{Da}[$ niel...e o proclamador do] 19 bem que anuncia a salva [cão é aquele do qual está escrito que [ele o enviará "para consolar os aflitos, para vigiar sobre os aflitos de Sião",] (Is 61:2) 20 "Para conso[lar os aflitos", sua interpretação:] para instruí-los em todos os tempos do mun]do...] 21 em verdade. [...] $22[\ldots]$ ela foi apartada de Belial e ela [...] 23 [...] nos juízos de Deus como está escrito sobre ele: "dizendo a Sião: 'teu Deus reina'. ["Si]ão", é 24 [a congregação de todos os filhos de justiça, os] que estabelecem a aliança (Is 52:7), os que evitam andar [pelo ca] minho do povo. "Teu Deus", é 25 [...Melquisedec, que os livra]rá da mão de Belial. E o que diz: "Fareis soar o chi[fre em to]do o país (Lv 25:9). ${ }^{11}$

\section{O pouco que restou da Col. III também faz menção a Melquisedec:}

1 [Sua interpretação...] 2 e conheceis [...] 3 Deus [...] 4 e muitos [...] 5 [...]......] Melquisedec $[\ldots] 6$ a lei para eles $[\ldots]$ a mão $[\ldots]$ e ele anunciará $[\ldots] 7$ consumirão Belial com fogo $[. .$. Belial, e se rebelarão [...] 8 os desejos de seus corações [...] 9 as muralhas de Judá [...] as muralhas de Je[rusalém...] 10-20 (pouco restou dessa parte). ${ }^{12}$

Nesse texto de Qumran, como vimos, Melquisedec é representado como um ser celestial identificado com o espírito supremo da luz em oposição a Belial,

${ }^{11}$ CHARLESWORTH, James H. (ed.). The Dead Sea Scrolls: Hebrew, Aramaic and Greek texts with English translations. Tubingen: Mohr-Siebeck; Wesminster John Knox Press, 2002, vol. 6b, p. 264-273; MARTINEZ, Florentino García. Textos de Qumran: edição fiel e completa dos documentos do Mar Morto. Petrópolis: Vozes, 1995, p. 180-181. Acrescentei, ao texto em português, as fontes escriturísticas que não constam no original, mas que são assinaladas em outras edições.

12 Idem, ibidem. 
o espírito supremo das trevas, e o julgamento final ao qual se refere é parte da visão escatológica da seita do Mar Morto relativa ao final dos tempos (akharit haiamim). Como podemos notar, essa exegese se baseia em Lv 25, o qual se refere à legislação sobre o ano jubilar e que é interpretado à luz de Dt 15:2 e Is $61: 1$, porém escatologicamente. É bem provável que Belial, em outros textos qumrânicos - 4QAmram e 4Q280 -, seja a mesma figura denominada Melquiresha (rei da iniquidade) ou ainda Belial e Príncipe das Trevas. Por outro lado, Melquisedec seria identificado com o arcanjo Miguel, que assume um papel de salvador escatológico e juiz em outros escritos, como no Rolo da Guerra (1QM 13.10;16.6-8;17.7), também chamado de Príncipe da Luz (1QM 13.10-11;1QS 2.20-22;CD 5.17-19) ou ainda Príncipe da Verdade (1QS 3.24). Conforme F. Garcia Martinez e outros estudiosos, é muito provável que Melquisedec, representado como um sacerdote, aparece duas vezes nos textos qumrânicos conhecidos sob o nome Cânticos do Sacrifício do Sábado, em 4Q401 11,3 e 11Q17 ii 7. ${ }^{13}$ Em certos detalhes do 4QAmram (Visões de Amram) encontramos semelhanças com o Apocalipse das Semanas em 1 Enoque 91:12-17; 93:1-10 e o conteúdo do fragmento 4QEn8 encontrado em Qumran. Em 1Enoque 10:12, o julgamento é atribuído por Deus ao arcanjo Miguel, o que levou alguns estudiosos a identificar Melquisedec com essa figura divina. Mas a figura de Melquisedec, sob o aspecto de sua inserção mais ampla na literatura qumrânica, foi também visto como sendo o que anuncia e traz boas novas (mevaser), como o ungido (hamashiach), e podendo se identificar como o Mestre da Justiça (more tzedek), ou ainda como o profeta escatológico e mesmo como o messias davídico. ${ }^{14}$ Parece ter razão Martinez, o importante estudioso dos manuscritos, de que Melquisedec é descrito com as mesmas características na Regra da comunidade e no Documento de Damasco ao se referirem ao Príncipe da Luz (1QS iii 20; CD v 18) e como um duplo do arcanjo Miguel tal como está descrito no Rolo da Guerra (1QM xvii 6-7). ${ }^{15}$ Nisso não há nenhuma contradição, uma vez que, nas Visões de Amram se afirma claramente que os dois chefes dos exércitos celestes têm três nomes (4Q544 3,2) e um dos nomes daquele que domina sobre as trevas é o de Melquiresha, antônimo de

${ }^{13}$ Vide o importante artigo de MARTINEZ, Florentino García. Las tradiciones sobre Melquisedec en los manuscritos de Qumran. Bíblica, vol. 81, 2000, fasc.1, p. 70-80, p. 70. Em 4Q401 11,3, Melquisedec aparece como sacerdote: "[Melqui]sedec, sacerdote na assemb[leia de Deus]" e no 11Q17 ii 7: "os chefes dos príncipes dos sacerdócios maravi]lhosos de Melqu[isedec]".

${ }^{14}$ Vide verbete Melchizedek (11QMelch) in: ASTOUR, Michael C. Melchizedek. In: FREEDMAN, David Noel (ed.). The Anchor Bible Dictionary, op. cit., vol. 4, p. 687.

${ }^{15}$ MARTINEZ, Florentino García. Las tradiciones sobre Melquisedec en los manuscritos de Qumran. Bíblica, vol. 81, 2000, fasc. 1, p. 73-74. 
Melquisedec (4Q544 2,3-5). Daí poder-se concluir sobre a existência de uma ou várias tradições na apocalíptica judaica relativas a Melquisedec que se revelaria na seita de Qumran e que passaria também ao nascente cristianismo, sofrendo uma nova interpretação e significado, como podemos verificar na Epístola dos Hebreus. David Flusser, em seu estudo intitulado "Melquisedeque e o Filho do Homem", ${ }^{16}$ aborda o paralelismo das passagens que se referem a Melquisedec no texto de Qumran, como juiz no juízo final, e que apresentam uma semelhança com a figura do Filho do Homem nas passagens do Livro de 2 Enoque, ${ }^{17}$ em que Melquisedec é descrito como tendo sido concebido pela esposa de Nir, irmão de Noé, pela palavra de Deus, sendo levado pelo arcanjo Miguel ao paraíso para que não sofresse durante o dilúvio nascido. $O$ verso 3 do salmo 110, pleno de múltiplos sentidos - "Pois desde o nascer tens o principado, nos esplendores da santidade: antes da aurora Eu te gerei, como o orvalho"18 - poderia ser interpretado do mesmo modo que o faz o Livro dos Segredos de Enoque, isto é, como sendo "a palavra de Deus gerou" Melquisedec no útero da mãe. Nos Evangelhos, o filho do homem aparece na resposta que Jesus dá ao sumo sacerdote ao ser inquirido se ele era o messias (Mt 22:44; Mc 12:36; Lc 20:42-43) e sua resposta será: "Desde agora, o Filho do Homem se assentará à direita do poder de Deus” (Mt 26:64; Mc 14:62; Lc 22:69). ${ }^{19} \mathrm{O}$ salmo 110 contém as expressões ou elementos que configuram a biografia mítica de Melquisedec e que se repetem nos Evangelhos ao se referir ao Filho do Homem, relativas à sua figura messiânico-escatológica, tais como "assentar-te à minha direita" (110:1) que se encontra em Mt 26:64; Mc 14:62; Lc 22:69, ou ainda "Ele julga as nações" (110:6) cujo sentido se revela em Mt 13:41-42. Porém, essa expressão "Filho do Homem" ou "o homem", que aparece na Bíblia hebraica no apocalipse de Daniel como uma figura redentoraescatológica (Dn 7:13; 7:17 ss) e como juiz do mundo, também possibilita uma associação com o messias davídico tal como o fez rabi Aquiba (TB, Sanhedrin 38 b). No Novo Testamento, a expressão, associada à figura de Jesus, não é absolutamente certa e o seu entendimento é extremamente complexo. ${ }^{20}$ Voltemos,

${ }^{16}$ FLUSSER, David. O judaísmo e as origens do cristianismo. Rio de Janeiro: Imago, 2000, vol.1, p. 209-215.

17 VAILLANT, A. (ed. e org.). Le Livre des Secrets d'Hénoch. Paris: l'Institut d'etudes slaves, 1952, p. $75-85$.

${ }^{18}$ A tradução da Bíblia LEB-Loyola é deficiente uma vez que não traduz a palavra "rekhem", útero materno, que também se encontra na versão grega da Septuaginta.

${ }^{19}$ FLUSSER, David. O judaísmo e as origens do cristianismo, op. cit., vol. 1, p. 213.

${ }^{20}$ KÜMMEL, Werner Georg. Síntese teológica do Novo Testamento. $4^{\text {a }}$. ed. São Paulo: TeológicaPaulus, 2003, p. 102-116. 
porém, à figura de Melquisedec que ainda aparece no Gênesis apócrifo, também conhecido como Apocalipse de Lamech, ${ }^{21}$ provavelmente elaborado entre o final do século 1 a. C. e primeira metade do 1 de nossa era, e constitui um texto próximo ao gênero do midrash rabínico, diferenciando-se do "pesher", qumrânico, aplicado em boa parte aos textos proféticos, que anuncia os acontecimentos do final dos tempos. No Gênesis apócrifo, a narrativa sobre Melquisedec é apenas uma paráfrase quase literal da narrativa bíblica, como podemos constatar pela leitura da coluna XXII desse texto:

Melquisedec, rei de Salem, tirou 15 comida e bebida para Abraão e para todos os homens que havia com ele. Ele era sacerdote do Deus Altíssimo. Abençoou 16 Abrão e disse: Bendito seja Abrão pelo Deus Altíssimo, Senhor do céu e da terra, e bendito seja o Deus Altíssimo 17 que entregou teus inimigos em tuas mãos. E (Abrão) lhe deu um dízimo de todos os gados do rei de Elam e seus aliados. ${ }^{22}$

A proximidade de conteúdo do Gênesis apócrifo com o livro de Jubileus, também denominado pequeno Gênese se encontra citado no Documento de Damasco (XVI, 2-4). Além de uma versão parcial latina, era conhecido durante muito tempo em sua versão etíope feita do grego que, por sua vez, seria a versão do original hebraico, recuperado apenas em pequena parte devido a um número de fragmentos encontrados dentre os manuscritos do mar Morto, o que aponta a importância do conteúdo de ambos os livros para os adeptos dessa seita. Do mesmo modo, essa afinidade deve se estender ao material presente nas Similitudes ou Parábolas de 1 Enoque (caps. 37-71), o que ainda é motivo de disputa entre os estudiosos que se dedicaram a entender os fragmentos encontrados em Qumran do pseudoepigráfico 1 Enoque. Por outro lado, afinidades podem ser estabelecidas, também, com certas partes do 2 Enoque, já lembrado acima, livro pseudoepigráfico de caráter apocalíptico, conhecido apenas pela versão eslavônica, e que contém, em sua parte final, uma referência ao nascimento de Melquisedec. ${ }^{23}$ Andrei Orlov, em seu artigo "Melchizedek legend of 2 (slavonic) Enoch" ${ }^{24}$ lembra a existência de múltiplas polêmicas com várias tradições sobre

${ }^{21}$ DUPONT-SUMMER, A. Les écrits ésseniens découverts près de la mer Morte. Paris: Payot, 1990 (primeira edição em 1959), p. 291-306.

${ }^{22}$ MARTINEZ, Florentino García. Textos de Qumran: edição fiel e completa dos documentos do Mar Morto. Petrópolis: Vozes, 1995, p. 279.

${ }^{23}$ KAHANA, Avraham. Hasefarim Hakhitzonim (Os livros apócrifos). Tel-Aviv: Massada, 1960, v. I, p. 102-141.

${ }^{24}$ ORLOV, Andrei. Melchizedek legend of 2 (slavonic) Enoch. Journal for the study of Judaism. Brill, vol. 31, n. 1, 2000, p. 23-38. 
a prática e a sucessão sacerdotal dentro do judaísmo e que envolveria a figura de Melquisedec e, nesse sentido, há uma certa semelhança de ideias de Qumran com o 2Enoque.

Melquisedec ainda está presente em um tratado gnóstico-cristão, Codex IX,1, que faz parte do conjunto de manuscritos descobertos em 1945 em Nag Hamadi. Segundo o estudioso Berger A. Pearson, o texto é um apocalipse que contém revelações transmitidas por seres intermediários celestes a Melquisedec, "sacerdote do Altíssimo". Pearson considera que é um escrito cristão influenciado pela atmosfera de especulações sectárias judaicas da época sobre a figura de Melquisedec, tendo como preocupação central a relação deste com Jesus Cristo. Seu conteúdo concerne diretamente ao ministério, morte e ressurreição de Jesus e a postura antidocética, segundo Pearson, leva a associar o texto aos assim denominados melquisedequistas mencionados por Epifânio (Haer. 55). ${ }^{25}$ Outro aspecto central de seu conteúdo é a revelação da assunção de Melquisedec com o Cristo e salvador triunfante identificando a figura bíblica vetotestamentária com Jesus (na expressão de Pearson "Jesus é Melquisedec redivivus"). O texto ainda apresenta uma parte litúrgica que o associa a uma tradição gnóstica representada pelo Apocalipse de João e vinculada à figura bíblica de Seth que daria seu nome a uma corrente gnóstica daquele tempo. Provavelmente, tudo leva a crer que a identificação de Melquisedec com Cristo estaria presente em certos grupos cristãos, tal como o encontramos manifesto na Epístola dos Hebreus. É, fundamentalmente, através da Epístola dos Hebreus que o nome de Melquisedec adquirirá um significado maior no mundo cristão, juntamente com os escritos que acabariam constituindo o cânon do Novo Testamento. O capítulo 7 da Epístola dos Hebreus apresenta um verdadeiro desafio aos seus interpretadores, devido a certos versículos, ou melhor, às expressões que neles se encontram. No início, o capítulo retoma a narrativa do Gênesis 14:18-20, bem como a expressão do Salmo 110:4: "Tu és sacerdote para sempre, segundo a maneira [outros traduziram como "ordem"] de Melquisedec" repetido na integra no capítulo anterior, 5:6 ("sy hiereus eis ton aiona kata ten taksin Melkisedek"). A interpretação comum aceita sobre o significado do capítulo é de que Melquisedec e Cristo são reis da justiça e da paz (Salem-Shalom-Jeusalém) e, na aplicação de uma exegese tipológica, que o sacerdócio de Melquisedec, como "typos”, encontra

${ }^{25}$ ISIDORO DE SEVILHA. Etimologiae. OROZ, J.; MARCOS, M. A. (ed.). Madri: B.A.C., 1993, lib.VIII, 5,17, p. 694, ao falar dos melquisediquianos diz: "Melchisedechiani vocati por eo, quod Melchisedech sacerdotem Dei non hominem fuisse, sed virtutem Dei esse arbitrantur". Isidoro não menciona sua fonte. 
no sacerdócio de Cristo um novo sacerdócio, superior à velha ordem dos levitas e do sacerdócio de Aaron (Hb 7:1-10). O verso 7:3 que diz "Ele aparece sem pai (apator), sem mãe (ametor) e sem qualquer outro antepassado [genealogia] (agenealogetos), sem começo e fim de vida", permitiu a exegese de identificação como predecessor e como "typos" de Cristo, como "sacerdote para sempre". As questões concernentes ao grego desse capítulo não são poucas, mas o fundo de tradições existentes sobre Melquisedec no judaísmo da época da elaboração da Epístola dos Hebreus, cujo texto se destaca pela presença e uso de versículos da Bíblia hebraica, nos ajuda a compreender a múltipla leitura e exegese que se faz do capítulo $7 .{ }^{26} \mathrm{O}$ autor do já citado verbete "Melchizedek" no The Anchor Bible Dictionary, Michel C. Astour, enfatiza que a Epístola dos Hebreus foi dirigida a um grupo judeu-cristão com certa proximidade ao pensamento dos essênios ("The Epistle of the Hebrews was addressed to a group of Judeo-Christians of Essene background and aimed at overcoming their lingering attachment to the idea of an exclusively levitical priesthood"'). Na verdade, essa opinião foi aventada com convincente fundamentação por Yigael Yadin em seu importante artigo "The Dead Sea Scrolls and the Epístle to the Hebrews". ${ }^{27}$ Para o autor da Epístola dos Hebreus a identificação de Melquisedec como "typos" de Cristo é a demonstração do sacerdócio de Jesus mesmo não tendo a ancestralidade levítica, precedido pela figura de Melquisedec, enfatizado nos Heb 5:6; 6:20; 7:17, nos quais se encontra o verso do Salmo 110:4, "Tu és sacerdote para sempre...”. O autor da Epístola aos Hebreus interpreta que o gesto de Abrão, descendente de Levi, ao pagar o dízimo do botim que havia reunido após a vitória sobre seus inimigos, indicava que Melquisedec era superior (7:6-10):

Pelo contrário, Melquisedec, que não era descendente de Levi, recebeu o dízimo de Abrão; mais ainda, abençoou ao mesmo, que era o depositário da promessa. Ora, sem a menor dúvida, o inferior é que é abençoado pelo superior. Além disso, os que aqui recebem os dízimos são homens mortais; mas lá é aquele de quem as Escrituras atestam estar vivo. Antes, pode-se dizer que é o próprio Levi, cujos descendentes recebem os dízimos, que

${ }^{26}$ VAN DER PLOEG, J. L'Ancien Testament dans l'Épitre aux Hebreux. In: Revue Biblique, n. 2, abril, 1947, p. 187-228.

27 YADIN, Yigael. The Dead Sea Scrolls and the Epístle to the Hebrews. In: Scripta Hierosolymitana. Jerusalém: Magnes Press, 1965, vol. IV, p. 36-55. 
os pagou na pessoa de Abrão; na verdade, Levi ainda estava no corpo de seu antepassado Abrão, quando Melquisedec foi ao seu encontro.

Em suma, a Epístola aos Hebreus, segundo Van der Ploeg, ${ }^{28}$ vê, em Melquisedec, uma "figura" de Cristo por vários motivos, a saber: a) seu nome é explicado como significando "rei da justiça", o que se coaduna com muitas profecias messiânicas nas quais o messias é representado como um rei justo por excelência e, portanto, se aplica também a Cristo (7:2); b) ele é rei de Salem, que se pode interpretar como "rei da paz", que é também um título messiânico, cf Is.9:5; c) o sacerdócio de Melquisedec é elevado e está acima dos levitas, porque ele recebeu os dízimos de Abrão, pais de Levi (7: 9-10), o que o aproxima do sacerdócio de Cristo; d) Melquisedec abençoou a Abrão, que havia recebido as promessas messiânicas, o que prova que ele era mais elevado do que o ancestral do povo de Israel (7: 7); e) ele é "apator, ametor, agenealogetos, mete aechen hemeron mete zoes telos echon, afomoiomenos de to yio tou teou menei hiereus eis to dienekes" (7: 3), e não pertence à tribo de Levi, assim como Jesus. Seguindo de perto essa linha interpretativa, D. W. Rooke a aprofunda no sentido de dar uma ênfase maior a elementos existentes de uma ideologia real ou monárquica, ao interpretar os versos do capítulo 7 da Epístola aos Hebreus, afirmando que o autor do texto mostraria um Jesus como uma verdadeira figura messiânica, em cuja pessoa o sacerdócio e a monarquia convergem seguindo uma tradição em que o rei também exerce a função de sacerdote, não comum ou funcional, mas pela sua própria natureza e condição que a divindade lhe atribuiu. ${ }^{29}$

Curiosamente, no mesmo tempo que se dava(m) a(s) leitura(s) da figura de Melquisedec como ser celestial, escatológico, messiânico, cristológico, encontramos, nos dois autores judeus de maior destaque do período do Segundo Templo, isto é, em Filo de Alexandria e Flávio Josefo, uma visão totalmente diferente, ou seja, voltada ao texto da narrativa histórica do Gênesis à qual é aplicada uma interpretação alegórica que se refere ao rei e ao sacerdote, sendo o rei diferenciado do déspota, assim como a alma do corpo e suas paixões, entre outras coisas. Tanto Filo quanto Josefo desconhecem inteiramente as interpretações da literatura apócrifa e pseudoepigráfica acima mencionadas e não há

${ }^{28}$ VAN DER PLOEG, J., op. cit., p. 214-215.

${ }^{29}$ ROOKE, Deborah W. Jesus as royal priest: Reflections on the interpretation of the Melchizedek tradition in Heb 7. In: Biblica, vol. 81, 2000, fasc. 1, p. 81-101. Rooke usa o termo "ontológico" para diferenciar a natureza e a função sacerdotal intrínsecas ao rei da função sacerdotal comum ou funcional, o que dá maior peso ao significado, assim me parece, da expressão rex-sacerdos usada posteriormente. 
qualquer referência à de Qumran, ainda que eles soubessem da existência da seita dos essênios sobre os quais nos deram um raro e precioso retrato. Filo, em sua obra Legum Allegoriae (Interpretação alegórica) III, xxv-xxvi, $79-82,{ }^{30}$ assim se expressa sobre Melquisedec:

Melquisedec, Deus o fez rei da paz, pois este é o significado de "Salem" e seu sacerdote. Ele não planejou de antemão sua atuação, mas o criou para se iniciar como rei pacífico e digno para o seu sacerdócio. Por isso ele foi chamado de "rei justo", e um "rei" é um ser que é o oposto a um déspota, pois enquanto um é autor de leis o outro é de atos ilegais. Assim, o déspota decreta leis severas e danosas para a alma e o corpo, levando a dolorosos infortúnios, ou seja, induzindo à maldade e à tolerância ilimitada das paixões. Mas o rei, em primeiro lugar, recorre à persuasão em lugar de decretos e, somente em último caso, os promulga como instruções o que permite ao ser humano, como se faz com um barco para que tenha uma boa e bem sucedida viagem, seja bem pilotada por um bom piloto, o que é a orientação correta. Portanto, o déspota pode ser intitulado como senhor da guerra e o rei o príncipe da paz, de Salem, que oferece à alma o alimento pleno de alegria e prazer; pois ele trouxe pão e vinho... xxvi - Mas deixe Melquisedec oferecer vinho em vez de água, a fim de ofertar às almas bebida vigorosa para que elas sejam tomadas por uma intoxicação divina, mais sóbria que a própria sobriedade. Porque ele é um sacerdote que tem sua parte no Logos, que nele se manifesta e é, pois todos os seus pensamentos sobre Deus são elevados, profundos e sublimes: porque ele é sacerdote do Altíssimo... ${ }^{31}$

Também Josefo, ainda que sem qualquer interpretação alegórica, repete a narrativa bíblica e parte do que encontramos em Filo de que

Abraão foi recebido pelo rei de Solyma, Melquisedec, e seu nome significa "rei justo", e de fato ele assim o era, e por aceitação de todos e por essa razão foi feito sacerdote de Deus; Solyma na verdade era de fato o lugar que foi posteriormente chamado de Hierosolyma (Ant 1.10.2 pr. 180).

A “figuração" de Melquisedec na Epístola aos Hebreus será o ponto de partida para a interpretação cristã posterior que será amplamente utilizada na polêmica antijudaica dos primeiros séculos de nossa era. Marcel Simon, em sua obra clássica, lembra que a exegese alegórica cristã empregada nessa literatura considera os rituais judaicos como uma prefiguração dos rituais cristãos, a exemplo da circuncisão que é vista como a imagem do batismo ou ainda o cordeiro pascal

\footnotetext{
${ }^{30}$ COLSON, F. H; WHITAKER, G. H. (eds.). Philo. Londres: Loeb Classical Library, vol. 3, 1930, p. $352-355$.

31 Idem, ibidem.
} 
como a da eucaristia, entre outros que poderiam ser lembrados. ${ }^{32}$ Melquisedec, o sacerdote de El Elion, que figurará, através dessa exegese, como sendo o sacerdócio cristão ("segundo a ordem de Melquisedec") terá um significado central no rol dos argumentos enunciados entre os autores da Patrística que procuraram demonstrar o quanto a Velha Aliança estava suplantada. João Crisóstomo, na Homilia contra os Judeus (PG, 48,922) e no De Melch. (PG, 56, 268), afirmará que o sacerdócio cristão, segundo a ordem de Melquisedec, suplantou o dos judeus. ${ }^{33} \mathrm{O}$ sacerdócio de Melquisedec é visto como mais antigo que o de Aaron e, na apologética cristã, tal prioridade preenche uma dupla função: ao mesmo tempo em que ela situa as instituições rituais do cristianismo nas origens da revelação, ela revoga o privilégio da anterioridade de Israel em relação a sua vocação divina. Melquisedec é visto como um ser estrangeiro, não hebreu, e aquele que é considerado o patriarca do povo eleito se submete àquele que o antecedeu, isto é Melquisedec, cujos títulos são mais antigos que os de Israel e ele representa não apenas um povo, mas todos os povos, confundindo-se com a Igreja dos gentios. Melquisedec oferece a Deus pão e vinho e não oferendas sangrentas como fez Abraão, evidenciando a sua diferença com o sacerdócio de Aaron. A partir da interpretação que se encontra na Epístola dos Hebreus, a literatura patrística dos primeiros séculos de nossa era fará um duplo uso polêmico de Melquisedec, visando combater grupos ou personalidades dissonantes da teologia oficial como sendo a do consenso da Igreja e, por outro lado, confrontarse-á com o judaísmo que, nesse tempo, ainda se mostrava ativo na afirmação exclusivista de seu monoteísmo e, portanto, aberto ao proselitismo, assim como o era o cristianismo. O notável estudioso da literatura patrística, G. Bardy, em artigo intitulado "Melchisédec dans la tradition patristique", ${ }^{34}$ tratou do tema e elencou boa parte das fontes cristãs antigas nos transmitindo a multiplicidade de suas exegeses. ${ }^{35}$ É digno de nota certa passagem no mencionado estudo de Bardy ao se referir ao artigo pioneiro de M. Friedlaender, publicado sob o título " $\mathrm{La}$ secte de Melchisédec et l'Épitre aux Hébreux", ${ }^{36}$ em que o autor aventa "a hipótese de que havia em Alexandria, naquele tempo, uma seita de melquisedecianos

${ }^{32}$ SIMON, Marcel. Verus Israel, étude sur les relations entre chretiens et juifs dans l'Empire Romain (135-425). Paris: Éditions E. de Broccard, 1948, p. 110-111; 205-206.

${ }^{33}$ Ibidem, p. 206.

${ }^{34}$ BARDY, G. Melchisédec dans la tradition patristique. In: Revue Biblique, 35, 1926, p. 496-509; 36, 1927, p. 25-45.

${ }^{35}$ É nesse rico trabalho de G. Bardy que me baseei para examinar as fontes patrísticas sobre o tema.

${ }^{36}$ FRIEDLAENDER, M. La secte de Melchisédec et l'Épitre aux Hébreux. In: Revue des Études Juives, t. 1882, p. 1-26, 188-198; t. VI, 1883, p. 187-199. 
derivada do essenismo e destinada a dar nascimento às diversas gnoses cristãs sem se apoiar sobre nenhuma prova". Podemos supor que Friedlaender, tanto quanto Bardy, ficariam surpresos se soubessem da descoberta dos textos de Nag Hammadi e de Qumran relativos a Melquisedec que, de certa modo, vêm ao encontro de sua hipótese, e isso muitos anos após ter escrito seu artigo. Mas o importante, no artigo de Bardy, é a constatação da multiplicidade de argumentos que os padres da Igreja souberam extrair da narrativa vetotestamentária, bem como da interpretação que se encontra na Epístola aos Hebreus sobre Melquisedec. Apesar da observação de Bardy sobre a radical interpretação alegórica da Epístola aos Hebreus fazer do rei de Salem um ser celestial com caracteres superiores aos da natureza humana, isso não impediu, no entanto, que os primeiros escritores cristãos se mantivessem próximos à literalidade da narrativa bíblica, isto é, que Melquisedec permanecesse como o sacerdote do Altíssimo que bendisse a Abraham. ${ }^{37}$ Mas, devemos observar que, em Justino, Melquisedec é figurado como "sacerdote dos incircuncisos e ele abençoou a Abrão na circuncisão após este lhe oferecer os dízimos... e que Ele receberá e abençoará os da circuncisão que a Ele se aproximarem, quer dizer, que creem Nele e buscam suas bençãos" ${ }^{38}$ Do mesmo modo, Teófilo de Antioquia ${ }^{39}$ repete os versos bíblicos dentro de uma narrativa histórica do Gênesis. O combativo padre da Igreja latina Tertuliano se manterá dentro dessa linha interpretativa retomando, porém, a preocupação com o tema do sacerdócio ao argumentar que antes da lei mosaica revelada no Sinai, da qual os judeus tanto se orgulham, certamente deveria existir uma lei à qual se deveria obedecer, senão, qual seria a razão para que Melquisedec fosse chamado sacerdote do Altíssimo antes do sacerdócio da lei levítica? E, em relação à circuncisão, qual teria sido sua importância se Melquisedec e outros patriarcas não o foram $?^{40}$ Diferentemente, Clemente de Alexandria

${ }_{37}$ É o caso de Justino, o Mártir, no Dialogus cum Tripho, 33, PG, VI, 545. Utilizei-me da edição da BAC (Biblioteca de Auctores Cristianos), intulado Padres apologistas griegos (s. II), Madri, 1954, p. 355.

${ }^{38}$ Cf. JUSTINO. Diálogo con Trifón. In: Padres apologistas griegos. Trad. Daniel Ruiz Bueno. Madri: BAC, 19, [4], 1954, p. 332. Justino argumenta contra a circuncisão que somente começa com Abraão, mas que nem Lot, Noé e Melquisedec eram circuncisos. Porém, Justino está equivocado, uma vez que, nesse encontro com Melquisedec, Abraão ainda não era circuncidado, o que acontecerá mais tarde (Gn 17:24). Tertuliano, Adversus Iudaeos 3:1; Adversus Marcionem 5:9, 9, comete o mesmo erro e certamente extraiu o argumento da obra de Justino.

${ }^{39}$ Ad Autolyc. II, 31; PG, VI, 1104 B; Padres apol. griegos, op. cit., p. 825.

${ }^{40}$ Adversus Iudaeos, 2, PL II, 600 B; 3, PL, II, 602. Atualmente, as passagens de Tertuliano concernentes ao nosso tema, bem como a de outros padres da Igreja e autores latinos, poderão ser facilmente localizadas na Library of Latin Texts. Turnhout: Brepols Publishers, 2002. Devo agradecer à dra. Martine Malinski que me indicou a existência da coleção digitalizada na Biblio- 
alegoriza o ato do oferecimento do pão e do vinho como figurando a eucaristia ${ }^{41}$ ou Cipriano que compara o sacrifício do sacerdote do Altíssimo com o de Cristo que se mostrou ainda mais elevado ao oferecer a Deus o pão e o vinho, isto é, seu corpo e seu sangue. ${ }^{42}$ Porém, de acordo com Bardy, Jerônimo, em uma de suas epístolas, ${ }^{43}$ lembra que Orígenes havia ensinado que Melquisedec era um anjo, o que não corresponde ao que se encontra em sua obra, senão apenas a afirmação de que os homens podem ser sumo-sacerdotes segundo a ordem de Aarão e somente Cristo o pode ser segundo a ordem de Melquisedec. ${ }^{44}$ Todos esses autores, lembrados por Bardy no artigo acima citado, nos dão uma ideia da crescente importância de Melquisedec na exegética cristã dos primeiros séculos de nossa era. No período que corresponde ao final do segundo século e início do terceiro, encontramos, em Roma, uma intensa fermentação teológica na qual Melquisedec é tema para novas interpretações, conforme podemos constatar na obra dos heresiólogos da época, ao se referirem aos desvios da fé em tempos passados e em seu tempo. Segundo Bardy, é entre os discípulos de Teódoto de Bizâncio (final do século II), que fora excomungado pelo papa Victor em 190, ${ }^{45}$ que novas interpretações sobre Melquisedec se desenvolveram. Hipólito, em sua obra, Refutação de todas as heresias, menciona um Teódoto, de modo pouco claro, e não ficamos sabendo a quem exatamente se refere, pois as fontes se referem a outro com o mesmo nome acunhado de "cambista". ${ }^{46} \mathrm{Seu}$ seguidor foi um tal de Artemon, excomungado pelo papa Zeferino. Artemon é mencionado por Eusébio de Cesareia que cita um anônimo que escreveu contra aquele herege. ${ }^{47}$ Outra fonte, o Pseudo-Tertuliano, ${ }^{48}$ informa que Teódoto teria

théque S. Génevieve de Paris.

${ }^{41}$ Stromateis, IV, 161, 3.

${ }^{42}$ Cipriano, Epistulae LXIII, 4 cf. na Library of Latin Texts: "Nam quis magis sacerdos dei summi quam dominus noster Iesus Christus, qui sacrificium deo patri optulit et optulit hoc idem quod Melchisedech optulerat id est panem et vinum, suum scilicet corpus et sanguinem".

${ }^{43}$ Epistulae LXXIII, 2. Cf. a Library of Latin Texts: "statim que in fronte gneseos primam omeliarum origenis repperi scriptam de melchisedech, in qua multiplici sermone disputans illuc devolutus est, ut eum angelum diceret, isdem que paene argumentis, quibus scriptor tuus de spiritu sancto, ille de supernis virtutibus est locutus".

${ }^{44}$ In Ioan. I, 2, 11.

${ }^{45}$ Vide sobre ele na obra de QUASTEN, J. Patrologia. Madri: BAC, 1961, vol. I, p. 254, 269, 318.

${ }^{46}$ Eusébio, em sua Historia Ecclesiastica. Madri: BAC, 1973, V, 28,9, p. 338-40, menciona que era discípulo do anterior e era acunhado de "Seleiro". Na tradução latina da Historia Ecclesiastica, feita por Rufino, da coleção Library of Latin Texts, lemos no lib. I, 3,17: "hic autem Melchisedech in divinis voluminibus sacerdos fuisse dei summi refertur, sed qui non oleo communi perunctus sit, neque qui ex successione generis susceperet sacerdotium, sicut apud Hebraeos dieri mos erat"..

${ }^{47}$ Historia Ecclesiastica, V, 29, 9; na edição da BAC, V, 28, 1ss., p. 339.

${ }^{48}$ Adversus omnes haereses 8; PL II, 72-74 e na Library of Latin Texts (fonte pub. da CSEL): “Alter 
ensinado que Cristo, ainda que fosse um homem, nasceu em condições não comuns às leis da natureza e que é o advogado dos homens perante Deus, e Melquisedec representa as mesmas funções de advogado e intercessor em favor dos anjos, como Cristo em relação aos homens, o que o eleva à categoria de um ser celestial. No Panarion, do heresiólogo Epifânio, temos a designação de melquisedecianos àqueles que, talvez, fossem os seguidores de Teódoto, e Bardy aventa a possibilidade de que alguns de seus discípulos ensinariam a superioridade de Melquisedec sobre Cristo ${ }^{49}$ trazendo, em outro lugar, elementos informativos sobre a genealogia de Melquisedec, bem como um número de opiniões, de diversas origens, que anotou em sua obra, entre as quais a de um certo Hiéracas que viveu no século IV, de que Melquisedec é idêntico ao Espírito Santo, ${ }^{50}$ opinião essa compartilhada com o assim chamado Pseudo-Agostinho. Esse autor, que escreveu o Liber quaestionum Veteris et Novi Testamenti é autor de um tratado sobre Melquisedec (quaestio 109) que seria de conhecimento de Jerônimo. ${ }^{51}$ Epifânio traz, em sua obra, a indicação de que, para os samaritanos, Melquisedec não é outro senão Sem, filho de Noé. ${ }^{52}$ Com razão e conhecimento, Jerônimo dirá que essa opinião é aceita entre os judeus. ${ }^{53}$ Outra opinião que se encontra em Epifânio é a de que os judeus acreditam que Melquisedec era justo e bom e sacerdote do Altíssimo, mas era filho de uma prostituta, ${ }^{54}$ razão pela qual

post hunc theodotos haereticus erupit, quei et ipse introduxit alteram sectam: et ipse hominem christum tantummodo dixit ex spirito sancto et ex virgine maria conceptum pariter et natum, sed hunc inferiorem esse quam melchisedech, eo quod dictum sit de christo: tu es sacerdos in aeternum secundum ordinem melchisedech." "Nam illum melchisedech praecipua ex gratia caelestem esse virtutem, et quod agat christus pro hominibus, deprecator et advocatus ipsorum factus, melchisedech facere pro caelestibus angelis atque virtutibus".

49 Epifânio, Haer., LV, 1,5.

${ }^{50}$ Epifânio, Haer., LV, 5, 1-3.

${ }^{51}$ Bardy, op. cit., p. 28.

${ }^{52}$ Epifânio, Haer. LV, 6,1.

${ }^{53}$ Epist. LXIII, 5,4; 9,2; Quaest. Hebraicae in Genes., PL, XXIII 961A; Comment. in Psalm. XXIV, 414B. O conhecimento dessa identificação de Sem e Melquisedec entre os judeus continuará e se manifestará também entre os escritores cristãos da Idade Média, entre muitos outros, tais como Rupert de Deutz (Rupertus Tuitiensis- c.1070-1129), que no De sancta trinitate et operibus eius (Library of Latin Texts) escreve: "de rege sodomorum qui egressus est illi in occursum et de melchisedech et quod hebraei tradunt hunc fuisse sem filium noe". O mesmo encontramos na Crônica de Salimbene de Adam (1221-c.1290) (Library of Latin Texts): "Item Hebraei etiam dicunt quod Melchisedech et Sem filius Noe idem homo fuit" ou ainda, bem antes, Sedulius Scotus (c. 848-860/874?), In evangelium Matthaei (vol. 1, lib. 1, cap. 2, Library of Latin Texts): "Iudei asserunt Sem, filium Noe, quem dicunt Melchisedech, post diluvium primum in Syria condidisse urbem Salem, in qua regnum fuit eiusdem Melchisedech".

${ }^{54} \mathrm{O}$ mesmo se encontra, surpreendentemente, em Vincent de Beauvais, Speculum Historiale, 1,104 . 
a história não conservou o nome de sua mãe e jamais conheceu seu pai. ${ }^{55}$ Bardy lembra também que João Crisóstomo ${ }^{56}$ repete o mesmo, isto é, como sendo uma opinião difundida entre os judeus. Como veremos mais adiante, ao tratarmos de Melquisedec na literatura rabínica, o mesmo argumento será exposto pelos sábios judeus com clara intenção anticristã. Epifânio resumirá as diversas opiniões existentes na Igreja católica sobre Melquisedec enfatizando que, para uns, ele era filho de Deus que apareceu a Abraham sob a forma humana, como sendo uma verdadeira teofania. ${ }^{57}$ Bardy traz como sendo essa a opinião de Ambrosio. ${ }^{58}$ Outros entendem que Melquisedec é o pai de Jesus Cristo ${ }^{59}$ e o próprio Epifânio aceita a opinião de que ele era a figura do filho de Deus e que o oferecimento do pão e do vinho que fez ao Altíssimo era o símbolo da eucaristia. ${ }^{60}$ Jerônimo, defensor da ortodoxia, reafirmará a interpretação originária da Epístola aos Hebreus de que Melquisedec é a figura de Cristo e a atribui aos demais autores eclesiásticos ortodoxos. ${ }^{61}$ Como o demonstra Bardy, mesmo entre os autores ortodoxos não é possível encontrar uma perfeita harmonia de posições em relação ao nosso personagem. Um desses autores, do século V, é Marcus Eremita, autor de um escrito De Melchisedec ${ }^{62}$ que denuncia com vigor a existência de heréticos que cometiam erros em suas especulações sobre o sacerdote do Altíssimo, alvo de interesse maior nos séculos IV e V. No século VI, a heresia melquisedeciana se manifestará abertamente, conforme testemunho de Timóteo de Constantinopla:

Há os Melquisedecianos, esses que denominamos agora de Athinganes. Eles se glorificam com o Melquisedec do qual emprestaram seu nome. Eles habitam a Frígia. Eles não são nem hebreus, nem pagãos. Ainda que guardem o sábado, mas não circuncidam sua carne. Eles não permitem a ninguém tocá-los; mas se alguém lhes der pão e água, ou qualquer outra coisa, eles não se permitem que se lhes segurem suas mãos; eles solicitam aos que lhes dão presentes para que os coloquem sobre o solo, e tão-somente aquilo que thes oferecem é que tomam. Eles fazem o mesmo quando eles dão qualquer coisa a outrem.

55 Epifânio, Haer., LV, 7,1.

56 Na homilia de Melchisedec, 3, PG, LVI, 260.

57 Epifânio, Haer. LV, 7,3.

58 Ambrósio, De mysteriis, VII, 46 PL XVI, 404; De Abraham, I, 3,16; De fide ad Gratian. III, 11,88 PL XVI, 607; Pseudo-Ambrósio, De Sacramentis, IV, 3,10-12 PL XVI, 438.

59 Epifânio, Haer., LV, 9,11.

60 Epifânio, Haer., LV, 6,3-4.

${ }^{61}$ Jerônimo, Tract. de Psalm. 109, apud BARDY, op. cit., p. 29.

${ }^{62}$ De Melchisedec, PG LXV, 1137A. 
São chamados de Athinganes porque não ousam tocar em nada. Também, ao retornarem à santa Igreja de Deus, eles necessitam do batismo da salvação. ${ }^{63}$

Provavelmente Ambrósio de Milão, devido a certa semelhança com costumes judaicos adotados pelos melquisedecianos, indicaria uma origem judaica à sua doutrina.$^{64}$ No entanto, Ambrósio, no De sacramentis, interpretará a passagem do Gênesis como sendo Melquisedec o autor dos sacramentos deduzindo serem anteriores e "mais antigos dos de Moisés, que os judeus pretendem ter, e que o povo cristão começou antes dos inícios do povo judeu, e nós por predestinação e eles pelo nome". ${ }^{65}$

Porém, à medida que avançamos no tempo, notamos, nos autores eclesiásticos, uma tendência a se voltar à narrativa do Gênesis ou, mais especificamente, a tornar Melquisedec uma figura humana, afastando-se da interpretação da Epístola aos Hebreus, isto é, a da identificação com o filho de Deus, devido aos perigos potenciais que poderiam conduzir ao caminho da heresia, mesmo que os antigos padres a tivessem aceito e expresso em seus escritos. Daí certos autores terem se voltado para "elaborar" uma história de vida, ou genealogia de Melquisedec, como a de todo ser humano. É o que vemos ainda em um autor do século IV, Filastrius de Brescia, que pressentiu o quanto seria inconveniente não se considerar que nosso personagem não tivesse pai e mãe, como é da natureza humana, uma vez que se poderia cair em interpretações errôneas. ${ }^{66}$ Sob esse aspecto, um escrito atribuído a Atanásio, isto é ao Pseudo-Atanásio, desenvolve uma curiosa e elaborada lenda sobre Melquisedec que contém elementos judaicos e explora o encontro bíblico com Abrão, história que terá desdobramentos literários posteriores com diferentes versões. ${ }^{67}$ Marcel Simon, que reproduz o texto em seu artigo sobre o tema ${ }^{68}$ observa que o estudioso Israel Lévi havia chamado a atenção de

${ }_{63}$ Timóteo de Constantinopla, De recept. Haeretc., PG LXXXVI, 1,33BC, apud BARDY, op. cit., p. 37.

${ }^{64}$ Ambrósio, De fide, III, 11.88, PL, XVI, 607; vide GINZBERG, L. The legends of the Jews. Filadélfia: The Pub. Soc. of America, 1947, vol. V, nota 39, p. 325.

${ }^{65}$ Ambrósio. De sacramentis, De mysteriis. Paris: ed. Souces Chrétiennes, 1950, IV, 11, p. 81: "Ergo primo intellige sacramente haec quae accipis anteriora esse quam sunt Moysi sacramente quaecunque iudaei habere se dicunt et prius coepsse populum christianum quam coepisse populum iudaeorum, sed nos in praedestinatione, illum in nomine".

${ }^{66}$ Filastrius, Diversarum hereseon liber, apud BARDY, op. cit., p. 40. Na Library of Latin Texts: "sunt quidam heretici legentes in genesi de melchisedech sacerdote atque rege, qui erat in salem civitate tunc temporis ita nominata sub abraham beatissimo patriarcha, de quo ait scriptura, sine patre, sine matre eum fuisse genitum, cum sit hoc contrarium ita sentire".

${ }^{67}$ Pseudo-Athanasio, Hist. de Melchis. PG XXVIII, 525A. Vide LEVI, Israel. In: Revue des Études Juives, t. VIII, 1884, p. 197, apud BARDY, op. cit., p. 40-41.

${ }_{68}$ Melchisédech dans la polemique entre juifs et chrétiens et dans la légende. In: Revue d'Histoire 
que a narrativa era, na verdade, um plágio de um midrash judaico, no qual o herói central era Abrão e não Melquisedec. Narrativas do mesmo gênero e com certa semelhança, de caráter lendário-genealógico, encontramos em outras fontes cristãs antigas tais como no Chronicon Paschale ${ }^{69}$ e nos Anais de Eutiquio. ${ }^{70}$ Do mesmo gênero é a narrativa que se encontra na versão do Livro etiópico de Adão e Eva, que é uma composição cristã em que se mesclam tradicionais elementos judaicos e egípcios e que, talvez, tenha alguma ligação com a seita dos melquisedecitas. Nele, Noé, antes de morrer, conta a seu filho Sem para pegar "Melquisedec, o filho de Canaan, ao qual Deus escolheu de todas as gerações dos homens, para ficar ao lado do corpo de Adão após ter sido levado da arca até Jerusalém como o centro da terra e cumprir com o sacerdócio perante Deus". ${ }^{71} \mathrm{O}$ anjo Michael, então, levou Melquisedec, quando tinha quinze anos de idade, de seu pai e, após tê-lo ungido como sacerdote, o trouxe a Jerusalém, dizendo a seu pai que compartilhasse o segredo somente com Sem, o filho de Noé, uma vez que o Espírito Santo, falando de dentro da arca quando o corpo de Adão foi ocultado, saudou a Melquisedec como "a primeira criação de Deus". Sem, carregando pão e vinho e auxiliado pelo anjo, levou o corpo de Adão ao seu destino. "Melquisedec ofereceu o pão e o vinho sobre o altar que construíram próximo ao lugar onde o corpo de Adão foi depositado e, após, Sem partiu, deixando o jovem puro em sua roupagem feita de peles sob a única proteção do anjo, e ninguém na terra soube de seu paradeiro até que, finalmente, Abrão o encontrou". ${ }^{72}$ Outro aspecto importante que devemos considerar e que justifica a tendência entre certos autores da patrística a "humanizar" a figura de Melquisedec, é a concepção de que a vida e os ensinamentos de Jesus estão associados diretamente à religião de Abraão, restrita na Antiguidade somente aos hebreus e, agora, transformada em religião universal, orientada à conversão de toda a humanidade onde quer que ela se encontre. A idealização dos antigos personagens bíblicos como Melquisedec é parte da aspiração teológica cristã em afirmar que os cristãos compartilham com a religião dos antigos que foram dignos de reconhecer e testemunhar o Cristo, que foi revelado e viveu entre eles. Podemos encontrar essa visão na obra de Agostinho de Hipona bem como na de Eusébio de Cesareia. ${ }^{73}$

et Philosophie Religeuses, 1937, p. 58-93.

${ }^{69}$ PG XCII, 176B, apud BARDY, op. cit., p. 43.

${ }^{70}$ Euthiquius, Annal. PG CXI, 917-918, apud BARDY, op. cit., p. 43.

${ }^{71}$ The Jewish Encyclopedia. Nova Iorque, 1904-5, verbete Melchizedek, vol. VIII, p. 450.

${ }^{72}$ Idem, ibidem.

${ }^{73}$ Vide KOFSKY, Aryeh. Eusebius pf Caesarea and the Christian-Jewish polemic. In: LIMOR, Ora e STROUMSA, Guy G. (ed.). Contra Iudaeus, ancient and medieval polemics between 
Na tradição rabínica, Melquisedec é identificado com Sem, o que é, como vimos antes, confirmado por Jerônimo. ${ }^{74} \mathrm{O}$ fato dessa identificação aparecer no Targum, a paráfrase aramaica do texto bíblico, evidencia que tal identificação é antiga ${ }^{75}$ Marcel Simon, no artigo lembrado acima, explica que a identificação rabínica encontrada no Talmud entre Melquisedec e Sem, visa manter o personagem estreitamente ligado a uma descendência judia e sua ligação com um ancestral do patriarca Abraão, justificando a sua atitude (em doar o dízimo) e fazendo do rei-sacerdote o pai da raça originária de Israel, mantendo, desse modo, o prestígio da dinastia real e do sacerdócio no passado e também no presente. ${ }^{76}$ A imaginação rabínica, certamente associou a benção de Sem por Noé (Gen 9,26-27) que contém certa analogia na forma com a benção de Melquisedec a Abraão. Javé é chamado por Noé "Deus de Sem” e Melquisedec é apodado de sacerdote do Deus Altíssimo, o que identifica Javé com o Deus Altíssimo, e identifica Melquisedec com Sem. A benção de Sem por Noé é interpretada como a benção de Israel e a execração de Canaã "que seja escravo" (versos 26-27) dos filhos abençoados de Noé, indicando a sujeição dos canaanitas e identificando Sem com o futuro povo de Israel. Também a distribuição da terra feita por Noé entre seus filhos se configura, na literatura rabínica, como privilegiando Sem que recebe a porção central da terra, incluindo em especial a Terra de Israel. ${ }^{77}$ Podemos entender essa elaboração exegética se considerarmos o uso polêmico antijudaico de Melquisedec entre os primeiros pensadores cristãos acima lembrados, que deveria ter suscitado uma reação de autodefesa de parte dos sábios de Israel em um período de disputa e autoafirmação do cristianismo nos primeiros séculos de nossa era. Muitas das interpretações rabínicas surgiram da polêmica anticristã, o que explica a multiplicidade de textos que reafirmam a transferência do sacerdócio de Melquisedec a Abraão. ${ }^{78}$ A argumentação rabínica

Christians and Jews. Tübingen: J.C.B. Mohr, 1996, p. 80; SIRINELLI, J. Quelques allusions à Melchisédech dans l'oeuvre d'Eusèbe de Césarée. In: Studia Patristica 6, 1962, p. 233-247.

74 Jerônimo, Epist. LXXIII, 5; Quaest. In Gen. 14 PL,XXII, 639; XXIII, 961.

${ }^{75}$ Sobre isso vide o importante estudo de McNAMARA, Martin. Melchizedek: Gen 14,17-20 in the Targums, in rabbinic and early Christian literature. In: Bíblica, vol. 81, fasc. 1, p.1-31. McNamara traz as citações do Targum Neofiti, Targum Pseudo-Jonathan e dos Fragmentos de Targums (VNL e P) nos quais Melquisedec é identificado como sendo Shem.

${ }^{76}$ McNAMARA, op. cit., p.15, discorda de Marcel Simon quanto à intenção polêmica anticristã relativa à identificação de Melquisedec com Sem: "It is doubtful if there was any polemical tendentious intention, anti-Christian or otherwise, in the identification. The identification of Melchizedek with Shem, in any event, may well pre-date Christianity".

${ }^{77}$ Entre outras, a menção encontra-se nas fontes rabínicas TB Sanhedrin 91a; Gênesis Rabba, 1:2; Pirkei de R' Eliezer, 24. Vide verbete Shem na Encyc. Jud., op. cit., vol. 14, p. 1368-1370.

${ }^{78}$ SAMUEL, Krauss. The Jewish-Christian controversy from the earliest times to 1789. Ed. rev. 
visa enfatizar a centralidade religiosa de Abraão e diminuir a de Melquisedec e no Pirkei, de rabi Eliezer, fica claro que o argumento cristão sobre o gesto de Abraão, ao oferecer o dízimo, não tem um significado maior de reconhecimento, ou submissão, porque ele não o fez sobre seus próprios bens, mas sobre o botim de guerra trazido de Sodoma e Gomorra. E já vimos que a redação do versículo hebraico sob o aspecto gramatical deixa margem a uma interpretação diferente em relação ao dízimo, permitindo concluir que é Melquisedec que o ofertou a Abrão. No midrash Gênesis Rabba (Bereshit Raba) o pão e o vinho oferecidos a Abraão por Melquisedec são interpretados como o desejo deste em instruir o patriarca sobre as prescrições do sumo-sacerdócio, pois simbolizam o pão da proposição e o vinho da oferenda: ${ }^{79}$

R. Schmuel ben Nachman e nossos mestres. R. Schmuel disse: leis do sumo-sacerdócio lhe revelou, "pão" (lechem) - é o pão da proposição (lechem hapanim), "e vinho" (veiain) - são as libações (nesachim). Mas esse mesmo midrash parece responder a muito mais senão vejamos: "Rei de Salem-R. Itzhaq, haBavli (babilônio), diz: que nasceu circuncidado [Melquisedec] "trouxe pão e vinho, e ele era sacerdote do Deus Altíssimo" - R. Schmuel ben Nachman disse: Ele o instruiu nas leis do sumo sacerdócio. "Pão" - Esse é o pão da proposição, "e vinho" para as libações. Os nossos sábios dizem: a Tora foi revelada a ele, pois que está dito: "Vinde, comam do meu pão e bebam do vinho que misturei" ( $\operatorname{Pr}$ 9:5). "E ele era sacerdote do Deus Altíssimo" - R. Aba ben Kahana disse: Todo vinho, que está escrito na Torá, deixou um malefício, exceto esse. Disse R. Levi: Sequer nesse saímos ilesos, pois ali já foi revelado: "e eles os servirão e esses afligi-los-ão quatrocentos anos" (15:13).

Além do que já observamos acima, o que nos chama a atenção é a passagem inicial do midrash com as palavras "que [Melquisedec] nasceu circuncidado", condição indispensável para ser sacerdote, mas que contém uma clara conotação polêmica anticristã se considerarmos, o que vimos mais acima, a dispensabilidade da circuncisão existente na literatura patrística em relação ao sacerdócio e seu significado maior, antijudaico, em que o circunciso Abraão é submisso ao incircunciso Melquisedec, argumento extraído e fundamentado na Epístola aos Hebreus. Em outro midrash do Bereshit Raba (46:5), ${ }^{80}$ a ênfase sobre a circuncisão parece ter o mesmo caráter polêmico anticristão ao se referir a Malki-Tzedek:

William Horbury. Tübingen: J. C. B. Mohr, 1996, vol. 1, p. 11 e nota 25.

${ }^{79}$ Bereshit Rabba. Tel-Aviv: ed. Machbarot leSifrut, vol. I, 43:6, p. 314.

${ }^{80}$ Idem, vol. I, p. 344-345. Vide também SILVA, Clarisse Ferreira da. Melquisedec, segundo o midrash Raba. Trabalho de final de curso no Departamento de Línguas Orientais da Universidade de São Paulo, 2005. 
R. Ishmael e R. Akiva. R. Ishmael diz: Abraão era sumo-sacerdote, porque está dito: "Quem jurou foi Javé Ele próprio, e Ele não vai arrepender-se: Para sempre tu és sacerdote à maneira de Malki-Tzedek" (S1 110:4), e está dito mais adiante: "E circuncidareis a carne de vosso prepúcio" (Gn17:11)...

Sem dúvida, a questão da circuncisão passará a ser um elemento polêmico determinante entre judaísmo e cristianismo dos primeiros séculos, desde que a concepção paulina acabou se impondo na nova religião. Daí a insistência de certas fontes rabínicas em afirmar que Melquisedec já nascera com o sinal do pacto de Abraão. ${ }^{81}$ Diversas passagens do Bereshit Raba enfatizam a passagem do sacerdócio, assim como a realeza, para Abraão:

"E Deus tentou Abraão" - ...R. Akiva diz: tentou-o certamente, pois senão não diriam: "Amedrontou-se, perturbou-se e não sabia o que fazer!" E disse-lhe: Abraão: "Eis-me" (22:1) - diz R. Yoshua ben Karcha: nos dois lugares comparou-se o próprio Moisés a Abraão, falou-lhe o Santo, bendito seja: "Não vangloria-te diante do rei e não te ponhas no lugar dos grandes (Prov 25:6). Abraão disse "Eis-me" - "Eis-me" para o sacerdócio, "Eis-me" - para a realeza, conseguiu o sacerdócio e conseguiu a realeza. Conseguiu o sacerdócio". Jurou Javé e não arrepender-se-á, tu és sacerdote para sempre, à maneira de Malki-Tzedeq" (S1 110:4); conseguiu a realeza: "Um príncipe de Deus tu és no meio de nós" (23:6). Moisés disse: "Eis-me (Ex 3:4), "Eis-me para o sacerdócio, eis-me para a realeza." Disse-lhe o Santo, bendito seja: "Não te aproximes daqui (Ex 3:5) - não há "aproximação" (Ex 3:5) refere-se ao sacerdócio, como se tu dissesses: "E o estranho que se aproximar será morto" (Nm 1:51), e não há "daqui” a não ser da realeza, como se tu dissesses: "porque trarão a mim até aqui" (IISm 7:18). Em ainda no mesmo lugar do Bereshit Raba (43:6) o próprio nome "Malki-Tzedek" (rei-justo) é interpretado como verdadeiro louvor a Jerusalém cujos habitantes se beneficiam de sua qualidade moral: "E Malki-Tzedek, rei de Salem, trouxe pão e vinho". "E Malki-Tzedek" - esse lugar faz justos seus habitantes. [outra coisa]. "Malki-Tzedek" "Adoni-Tzedek" (Js 10:1) - Jerusalém é denominada 'justiça' (tzedek), pois que está dito: "A justiça nela habitará" (Is 1:21).

Contudo, devemos observar que, até aí, a figura de Melquisedec, aos olhos dos sábios rabínicos, era ainda extremamente elevada e no Talmud colocam-no na mesma categoria de Elias, do Messias ben Joseph e do Messias ben David: "E mostrou-me Deus quatro ferreiros. Quem são estes ferreiros? R. Hana ben Bizna disse em nome de R. Shimon Hasida: Messias ben David e Messias ben Josef e

${ }^{81}$ Bereshit Rabba, 43:6, p. 314, onde R' Itzhaq Habavli interpreta “Melech Shalem” (rei de Salem) como sendo nascido circuncisado (she nolad mahul). Avot de R'Nathan 2, 2; vide GUINZBERG. The legends of the Jews, op. cit., vol. 5, nota 102, p. 226. 
Elias e Kohen-Tzedek", [ou Malki-Tzedek] ${ }^{82} \mathrm{O}$ texto talmúdico fundamenta-se no verso de Zacarias 2:3. Na literatura talmúdica, Elias, visto como profeta e sumo-sacerdote (kohen-gadol), desempenha um papel central para o tempo da vinda do messias, pois a ele cabe anunciá-lo. No entanto, a passagem talmúdica que usa e aplica a sinonímia "kohen-tzedek" ou "malki-tzedek" em relação a Elias, que será interpretado futuramente como o arauto do messias, não o faz com o mesmo sentido da Epístola aos Hebreus, ou seja, pré-figurando Melquisedec como o messias-salvador. Muito pelo contrário, sob esse aspecto, o Talmud expressa uma concepção claramente oposta à cristã, como podemos verificar no dito do "nassi" (patriarca) raban Shimon ben Gamaliel II, que viveu no período após os decretos antijudaicos de Adriano, ao interpretar o verso de Zacarias 4:14:

São os dois Ungidos que estão de pé junto ao Senhor de toda a terra!”, e que, seguindo a R'Yehuda, são Aarão e David: "É o kohen - tzedek e o Messias". E ele acrescenta: "E não sei qual deles é o mais querido, quando ele diz (Sl. 110:4): "Quem jurou foi Javé Ele próprio e Ele não vai arrepender-se: Para sempre tu és sacerdote para sempre [al dibrati (segundo) Malki-Tzedek]”.83

Klausner destaca o fato de que, para o sábio do Talmud, o texto enfatiza o messias como sendo o "mais querido", ou importante, considerando a versão que se encontra no Avot de R' Nathan, 51, na qual constam as palavras “pois sabes que o melech-hamashiach (o rei-messias) é mais querido do que o kohen-tzedek (o sacerdote justo)", minimizando o sacerdote. ${ }^{84}$ Por outro lado, é o próprio texto talmúdico de Nedarim 32b que apresenta a surpreendente argumentação resultante da imaginação exegética rabínica para explicar a transferência do sacerdócio de Melquisedec-Sem a Abraão:

E disse R' Zecharia em nome de R'Ishmael porque o Santo, bendito seja, quis tirar o sacerdócio de Sem, pois foi dito: "E ele é sacerdote do Deus Altíssimo" (Gn 14:18). Mas devido a que abençoou a Abraão antes de abençoar a Deus (o termo hebraico utilizado é "Makom", um dos nomes da divindade), a tirou, pois foi dito (Gn. 14: 19): "E o abençoou e disse: Bendito seja Abrão pelo Deus Altíssimo criador dos céus e da terra e bendito seja o

${ }^{82}$ TB Sucá52b. Utilizei-me da edição clássica bilíngue (hebraico/aramaico-alemão) do Talmud Bavli de Lazarus (Eliezer) Goldschmidt, Benjamin Harz Verlag, Berlin-Wien, 1925, bem como da reedição Mahadurat Peninim, com comentários e acréscimos, da Vagshal Pub. Ltd., Jerusalém, 1992-1999.

${ }^{83}$ A passagem em questão interpreta o que está escrito em Nedarim 32b. De acordo com KLAUSNER, J. Harayon hameshichi beIsrael (A ideia messiânica em Israel). $3^{\text {a }}$.edição. Tel-Aviv: Masada, 1960, p. 310.

${ }^{84}$ KLAUSNER, op. cit., p. 310 , nota 75. 
Deus Altíssimo". Disse-lhe Abraão: "Se abençoa o servo antes de abençoar o seu senhor?" De imediato foi dado a Abraão, como foi dito (S1 110:1): "Disse Deus ao meu senhor: venha assentar-te à minha direita até que Eu faça de teus inimigos um estrado no qual os teus pés repousam!” E está escrito após (S1 110:4): “Jurou Deus e Ele não vai arrepender-se: Tu és sacerdote para sempre, pela minha palavra (al dibrati = segundo ou a maneira de) Melquisedec, pela palavra de Melquisedec, pois está escrito: "E ele é sacerdote do Deus Altíssimo". Ele é sacerdote mas seus descendentes não são sacerdotes. ${ }^{85}$

A mesma narrativa encontra-se no midrash em Vaikra Raba (Leviticus Raba) 26:6:

Foi ensinado na escola de R. Ishmael: o Santo, bendito seja, visou fazer de Sem o progenitor do sacerdócio, pois diz, "E Melquisedec, rei de Salem... era sacerdote de Deus" (14:18). Mas quando ele abençoou Abraão antes de abençoar o Onipresente e Abraão disse a ele: "deve a benção do servo ter prioridade sobre a benção do Mestre?, o Santo, bendito seja, Ele, tomou o sacerdócio dele e deu-o a Abraão; como pode ser provado pelo fato de que se diz: "O Senhor disse ao meu senhor" (S1 110:1), e depois disso está escrito, "Jurou Javé e não arrepender-se-á: tu és sacerdote para sempre, segundo à maneira [ordem] de Malki-Tzedeq" (S1 110:4). Daí estar escrito, "Bendito seja Abraão pelo Deus Altíssimo que cria céu e terra" (Gn 14:19). R. Ishmael ${ }^{86}$ e R. Akiva concluíram diferentemente. R. Ishmael mantém que Abraão era Sumo Sacerdote. Desde que está escrito, "Jurou Javé e não arrepender-se-á: tu és sacerdote para sempre" e está escrito "fareis circuncidar a carne de vosso prepúcio" (Gn 17:11).

Acompanhando o que se encontra em Nedarim 32b, o midrash em questão tira o sacerdócio de Melquisedec para outorgá-lo a Abraão. Lembremos que a questão do sacerdócio é central na disputa entre judaísmo e cristianismo e não é demasiado enfatizar que a aplicação da antiga exegese alegórica cristã se perpetuará na Idade Média ao se referir ao salmo 110:4. Nesse aspecto, uma passagem em Jerônimo ilustra bem a visão conflitante entre a Igreja e a Sinagoga, ou entre o "carnale sacerdotium" e o "secundum ordinem Melchisedec", isto é o "spiritualis": "Moyses... id est lex Domini spiritualis, Aethiopissam de gentibus duxit uxorem. Et Maria (refere-se a Miriam, irmã de Moisés) id est synagoga

${ }^{85}$ GOLDSCHMIDT, op. cit., vol. IV, p. 903; VAGSHAL, op. cit., vol. 9.

${ }^{86}$ R' Ishmael, que viveu na mesma época de Justino, é autor de passagens polêmicas anticristãs na literatura rabínica. David Rokeah, em sua tradução ao hebraico da obra de Justino, Diálogo com Trifo judeu. Jerusalém: ed. Magnes Press, Universidade Hebraica de Jerusalém, 2004, p. 88, nota 232, lembra Tosefta, Hulin 2,22-23, ed. Zuckermandel, p. 503; TJ, Avodá Zará 2, 2a; TB, Avodá Zará 27b; Tosefta, Shabat 13, 5, ed. Lieberman; p. 58-59; TB, Shabat 116a. 
Iudaeorum; et Aaron, id est carnale sacerdotium, et non secundum ordinem Melchisedec, murmurant adversus legem, sed frustra..."

O exegeta medieval R. Schlomo Itzchaki (Rashi), ao comentar a passagem talmúdica de Nedarim 32b, diz que os descendentes de Abraão herdarão não somente o sacerdócio, mas também a realeza. A ênfase da centralidade de Abraão encontra-se em outros midrashim:

E abençoou-o e disse: "Bendito seja Abrão pelo Deus Altíssimo, que adquire (o verbo escrito com "alef" tem esse sentido) céu e terra" (14:19) - De quem adquire? R. Aba em nome de R. Kahana e R. Itzhaq. R. Aba disse: Abraão recebia viajantes. E depois de comerem e beberem, dizia a eles: Abençoem! E eles lhe diziam: O que diremos? E eles lhes dizia: Digam: "Bendito o Deus do Universo, porque comemos o que é Dele!" (é a oração que se costuma dizer após a refeição segundo o costume judaico). Disse-lhe o Santo, bendito seja: Meu Nome não é conhecido para as minhas criaturas e faças tu que ele seja conhecido entre minhas criaturas, e eu me elevo a ti como se tu estivesses associado comigo na criação do mundo. É o que está escrito: E abençoou-o e disse: Bendito seja Abrão pelo Deus Altíssimo, que adquire céu e terra. ${ }^{88}$

O midrash utiliza-se da benção de Melquisedec, que figura apenas como uma voz mediadora, para destacar os excepcionais méritos humanos de Abraão, por quem os povos da terra serão abençoados, méritos esses que o levam a "adquirir" sua participação associativa na criação do "céu e da terra" para difundir o Nome (do Deus Uno e Único) à humanidade. O Bereshit Raba ${ }^{89}$ ainda destacará outro mérito de Abraão que corroborará a centralidade do patriarca que prevalecerá em sua descendência e terá continuidade em Israel. É a benção recebida de Melquisedec após a oferenda do dízimo:

E lhe deu o dízimo de tudo" (Gn 14:20) - R. Yehuda ben Simon disse: da força dessa benção alimentaram-se as três grandes colunas no mundo: Abraão, Isaac e Jacó. Sobre Abraão está escrito: "E Deus abençoou Abraão em tudo (24:1) - graças a "e deu-lhe o dízimo de tudo." Sobre Isaac está escrito: "comi de tudo (27:33) - graças a "e deu-lhe o dízimo de tudo". Sobre Jacó está escrito: "porque Deus favoreceu-me e por isso tenho tudo" (33:11) - graças a "e deu-lhe o dízimo de tudo". Como Israel conseguiu a benção

${ }^{87}$ Jerônimo, in Sophoniam (Opera Exegetica) VI, 2, in Corpus Christianorum, S.L. 76 (Turnhout) 1970, p. 690. A mesma explicação encontra-se no comentário ao Numeros de Hrabanus Maurus, PL, CVIII, cols. 661-662; Bruno de Segni, PL, CLXIV, col.480. Vide BALFOUR, Mark. Moses and the Princess: Josephus' Antiquitates Judaicae and the chansons de geste, Medium Aevum, 64, 1995, nota 12 .

${ }^{88}$ Bereshit Rabba, 43:7, p. 315.

${ }^{89}$ Bereshit Rabba, 43:8, p. 315-316. 
dos sacerdotes? R. Yehuda e R. Nehemia e nossos sábios. R. Yehuda disse: de Abraão: "Assim (a palavra hebraica "ko") será tua descendência" (15:5). Assim (ko) abençoareis os filhos de Israel (Nm 6:23). R. Nehemia disse: de Isaac, porque foi dito: "E eu o jovem iremos até lá (ko) (22:5), depois disso disse o Senhor: "Assim (ko) abençoareis os filhos de Israel". E nossos sábios dizem: de Jacó, porque foi dito: “Assim (ko) dirás à Casa de Jacó" (19:3), e diante dele: "Assim (ko) abençoareis aos filhos de Israel”. R. Eleazar e R. Yossi ben Hanina. R. Eleazar disse: quando eu criei meus filhos como estrelas?. Como se revela a eles com "assim" (ko): “Assim (ko) dirá à Casa de Jacó”. E R. Yossi ben Hanina disse: quando se revela aos seus líderes com "assim” (ko): “Assim (ko) disse Deus: "Meu filho primogênito é Israel” (Ex 4:22).

O mérito do dízimo de Abraão, que representa o dízimo sacerdotal, adquire um significado transcendental através da benção divina a toda sua descendência. E é essa descendência que doravante carregará a responsabilidade do sacerdócio que, em princípio, seria atribuição dos primogênitos, mas que o "mérito", segundo o justo julgamento divino, poderia alterar. O midrash de Bamidbar Raba (Números Raba) (4:8), que traça uma verdadeira genealogia do início e da sucessão do sacerdócio em Israel, assim se expressa:

"Toma os levitas em lugar de todo primogênito dos filhos de Israel" (3:45) - Disseram nossos sábios: Por que ordenou o Santo, bendito seja, remir os primogênitos de Israel através dos levitas? Porque, no início, eram os primogênitos que serviam para o sacerdócio, até que surgiu a tribo de Levi, como ensinaram os nossos sábios: Até antes de ser levantado o santuário existiam os lugares altos permitidos e o culto [celebrado] pelos primogênitos. Mas quando foi levantado o santuário, proibiram-se os lugares altos [Lv 17:8] e o culto [passou a ser celebrado] pelos sacerdotes. E saiba, eram os primogênitos que faziam o sacrifício, enquanto não surgiu a tribo de Levi; entenda, no começo da criação do mundo: o primeiro homem foi o primogênito do mundo, e, por isso sacrificou seu sacrifício, porque está escrito: "E isso é melhor para Deus do que o touro, do que um novilho com chifres e cascos" (S1 69:32), vestiu vestes sumo sacerdotais, porque está escrito: "e fez Javé Deus para o homem e para sua mulher vestes de pele e os vestiu" (Gn 3:21) - e eram vestes especialmente dignas, e eram os primogênitos que as usavam. Uma vez que morreu o primeiro homem, transmitiu-as a Set, e Set transmitiu-as a Matusalém. Uma vez que morreu Matusalém, transmitiu-as a Noé. Surgiu Noé e ofereceu um sacrifício, porque está dito: "tomou de todo o animal puro... em holocausto no altar" (8:20). Morreu Noé, transmitiu-as a Sem [Melquisedec]. Mas acaso Sem seria o primogênito? Acaso não era Jafé o primogênito, porque está dito: "E a Sem... irmão de Jafé, o mais velho”. (10:21)! Então por que as transmitiu a Sem? Porque previu Noé que três dos pais se estabeleceriam através dele. E saiba, Sem ofertava, porque está dito: "E Melquisedec (Malki-Tzedek), rei de Salem... e ele era sacerdote do Deus Altíssimo (14:21) - e por que lhe foi conferido o sacerdócio? Mas não se conferiu o sacerdócio a não ser a Aarão! Mas é isso que diz 
aqui: "e ele era sacerdote?". Porque ofertava como os sacerdotes faziam. Morreu Sem e transmitiu-as a Abraão. Mas era Abraão primogênito? Senão porque era um justo foi transmitida a ele a primogenitura e sacrificou, porque está dito: "ofereceu-os em holocausto em lugar de seu filho" (22:13).

Novamente vemos a identificação de Sem com Melquisedec e, por outro lado, vemos o critério do "mérito" do justo sobrepor-se ao critério da primogenitura natural para se transformar numa primogenitura espiritual, firmada na fé incondicional e na conduta correta. Um midrash do Bereshit Raba, ${ }^{90}$ ao interpretar o nome "Jerusalém", associa-o aos "justos" aplicados a Abraão e Sem, ambos possuidores de progenitura de mérito ou espiritual:

"E chamou Abraão o lugar com o nome: Deus verá" (Gn 22:14): - R. Bevai, haGadol (o Grande), em nome de R. Yochanan: disse diante dele: Senhor do Universo, na hora que me disseste "Pegue então o teu filho, o teu único (22:2), deveria responder: ontem me disseste: "pois é por meio de Isaac que teu nome passará a tua descendência" (21:12), e agora tu the dizes: "Peque então o teu filho, o teu único"! Deus nos livre, não farei desse modo, mas sim contive minha misericórdia para fazer tua vontade, desse modo seja assim a tua vontade perante Ti, Javé nosso Deus, no momento que os filhos de Isaac se verem frente uma desgraça, terão que lembrar o mesmo sacrifício e se encherão de misericórdia. Abraão chamou [o lugar] "yre" (verá) porque está dito: "E chamou Abraão aquele lugar com o nome: Deus verá", Sem chamou-o "Salem", porque está dito: "Malki-Tzedek rei de Salem" (14:18). Disse o Santo, bendito seja: se eu chamá-lo "yre", tal como o chamou Abraão, Sem, homem justo, reclamará; e se chamá-lo "Salem", como chamou-o Sem, Abraão, homem justo, reclamará; mas eis que o chamo Yerushalem, assim como ambos o chamaram: "Yre Shalem" - Yerushalem.

Abraão é o protótipo do homem justo uma vez que não titubeou quando lhe foi ordenado a sacrificar o seu próprio filho. E quanto a Sem, vemos que o midrash o aponta como digno de ser chamado justo, ao ponto da divindade levá-lo em conta para compor o nome da cidade de Jerusalém. Mas não será essa a única etimologia entre os autores antigos para explicar o nome da cidade sagrada. ${ }^{11}$

A exegese judaica medieval, a começar de Rashi, segue a tradição já sedimentada na literatura rabínica mais antiga, isto é, do Talmud, do Targum e do Midrash. De fato, boa parte dos exegetas, ao comentar as passagens referentes a Melquisedec, citam essas fontes. Apenas a título de ilustração vejamos como alguns dos grandes exegetas medievais comentam os versos do Gênesis referentes

\footnotetext{
${ }^{90}$ Bereshit Rabba 56:10, vol. II, p. 434-435.

${ }^{91}$ Vide GUINZBERG, op. cit., vol. 5, nota 253, p. 253.
} 
a Melquisedec. Rashi, o exegeta por excelência, diz claramente: "Malki Tzedek: é o nome de Sem filho de Noé”. E, ao se referir ao "pão e vinho", esclarece que "assim se faz aos que voltam da guerra e lhe mostrou que não tem em seu coração [inimizade] por ter matado os seus filhos; lhe insinuou sobre as oferendas e libações que ali sacrificarão seus filhos..." R. Moshe ben Nachman, o Ramban, comenta, com certa amplidão, a expressão "Melquisedec, rei de Salem" e nos diz:

é Jerusalém pois está dito que "E em Salem está seu Tabernáculo" e Malki nos tempos de Josué [era chamado] Adoni-Tzedek, pois que, desde aquele tempo, sabiam os povos que aquele lugar foi escolhido como o centro dos habitantes [da terra?] ou sabiam de sua situação privilegiada pela tradição de que ele está orientado em direção ao Templo celestial onde habita a Schechiná do Santo, bendito seja, que se denomina Tzedek (Justiça). No Bereshit Raba esse lugar torna seus habitantes justos e Jerusalém é chamada Malki-Tzedek - Adoni-Tzedek. Tzedek porque foi dito "Tzedek (Justiça) nela habitará: "E ele é sacerdote do Deus Altíssimo", para fazer saber que Abrão não teria dado dízimo a um sacerdote de outros deuses, mas por saber que ele era sacerdote do Deus Altíssimo, e deu-lhe o dízimo em honra ao Nome, o que indica a Abrão por outro lado que ali será [edificada] a Casa de Deus e ali tirará sua descendência o dízimo e a oferenda, e ali abençoarão a Deus." "E na opinião de nossos sábios que dizem que Melquisedec é Sem, filho de Noé, que saiu de sua terra para ir a Jerusalém para ali cultuar a Deus...”

Em continuação, Nachmanides, exegeta e profundamente conhecedor da literatura rabínica, se refere também à narrativa sobre a divisão da terra entre os filhos de Noé e a parte que coube a Sem foi a Terra de Israel, além do material legendário que se encontra na literatura talmúdica, a qual mencionamos anteriormente, referente à recusa de Abraão de se apossar de todo o botim a fim de evitar que dissessem que ele se enriqueceu com a riqueza dos outros. O pensador e exegeta Abraham Ibn Ezra não inova e repete a explicação rabínica que seu nome é "Malki-Tzedek porque ele é rei de um lugar [denominado] Tzedek ou Justiça, e há os que dizem que ele é Sem. E Salem é Jerusalém e a prova está na expressão “em Salem está seu Tabernáculo” (S1 76:3). Em uma passagem do Zohar, o texto central da cabala judaica (I, 86b-87a), o versículo do Gn 14:18 é citado, mas o autor se concentra nas palavras do S1 76:3 “em Salem está seu Tabernáculo" para elaborar uma extraordinária explicação mística sobre a criação do mundo em que as diversas forças criadoras associadas à árvore sefirótica e às letras do Tetragramaton, Bina e Malchut, também denominado “Tzedek” (justiça), leva à ilação de ser um rei perfeito ou que reina sobre a perfeição, pois Shalem também significa "perfeito", o que simboliza e confirma que as forças criativas, 
aparentemente antagônicas, combinam-se e harmonizam na sua ação criadora final que é "perfeição" (Shalem, "perfeito", "completo"). ${ }^{92}$

Também na literatura polêmica judaico-cristã medieval, os argumentos utilizados são os mesmos que os tradicionais derivados da literatura patrística e sua leitura tradicional da Epístola aos Hebreus. É o que podemos constatar em Fulbert de Chartres (?-1028/1030) ao se referir ao sacerdócio de Cristo como eterno, fundamentado no Salmo 110: $4 .{ }^{93}$ Mas podemos encontrar, ainda na Alta Idade Média, em um enciclopedista como Isidoro de Sevilha, o conhecimento e a aceitação da tradição judaica que identifica Melquisedec com Sem e, ainda, que, após o dilúvio, ele construiu Shalem "que agora é chamada Jerusalém". ${ }^{94}$

Porém, no decorrer da Idade Média, Melquisedec será utilizado não apenas na polêmica religiosa tradicional entre as duas religiões monoteístas, judaísmo e cristianismo, senão que virá a sofrer uma interpretação associada à elaboração da teoria política na disputa entre os dois poderes, regnum et sacerdotium, ou seja, dos poderes temporal e espiritual. Não temos a intenção de estudar aqui o desenvolvimento dessa questão central, isto é, a história das relações entre os dois poderes desde que o cesaropapismo dos primeiros imperadores romanos, a partir de Niceia, começaria a ser contestado em função da doutrina governamental romano-petrina enfatizada pelo papa Leo I (440-461) com a clara intenção de se opor ao poder temporal do imperador. ${ }^{95}$ Interessa-nos, apenas, examinar o uso do "símbolo" Melquisedec no desenvolvimento desse processo e como foi aproveitado como argumento na disputa entre as duas instituições da sociedade cristã medieval. Segundo Ullmann, o papa Leo I foi o primeiro a introduzir a figura de Melquisedec na literatura papal. ${ }^{96}$ A elaboração da doutrina papal atribuía um papel protetor ao imperador assim como foi expresso por S. Ambrósio: "Imperator enim intra ecclesiam, non supra ecclesiam est". ${ }^{97}$ Em outros, equivale ao

\footnotetext{
${ }_{92}$ Vide LACHOVER, Fischel e TISHBY, Isaiah (ed.). The wisdom of the Zohar. An anthology of texts. Introd. e expl. I. Tishby. Trad. David Goldstein. The Littman Library of Jewish Civilization, 1994, 3 vol., vol. II, p. 567-568.

${ }^{93}$ BLUMENKRANTZ, B. Les auteurs chrétiens latins du moyen age sur les juifs et judaisme. Paris-La Haye: Mouton \& CO, 1963, p. 240.

${ }^{94}$ Isidoro de Sevilha, Chronicon, PL 83, 1017-1058. Nas Etimologiae, lib. XV, 1,5 ele dirá: “Iudaei adserunt Sem, filium Noe, quem dicunt Melchisedec, primum post diluvium in Syria condidisse urbem Salem, in qua regnum fuit eiusdem Melchisedech. Hanc postea tenuerunt Iebusaei, ex quibus et sortita vocabulum est Iebus; sicque duobus nominibus copulatis Iebus et Salem vocata est Hierusalem."

${ }^{95}$ ULLMANN, Walter. The growth of papal government in the Middle Ages. $2^{\mathrm{a}}$ ed. Londres: Methuen \& Co Ltd, 1962, p. 10-11.

${ }^{96}$ V. Sermo 3, cap. 2, Sermo 5, cap. 3, e também Sermo 4, cap. 1, apud ULLMANN, op. cit., p. 13.

${ }^{97}$ Ep. 21, cap. 36 (PL.xvi, 1007) apud ULLMANN, op. cit., p. 13.
} 
que Leo I expressou ao imperador Marciano: o corpus cristão foi fundado sobre a missão paulina e, como membro desse corpus, o imperador tem a função de protegê-lo. A regia potestas foi outorgada ao imperador para proteger a Igreja e assegurar a corporeitas omnium fidelium. ${ }^{98}$ Essa concepção reformulava o modelo antigo do "arkiereus basileus" ou a figura do "rex-sacerdos" e, com a afirmação do cesaropapismo, a partir da segunda metade do século V, o papado se viu obrigado a elaborar uma teoria que definisse a posição do imperador como parte da comunidade cristã e do corpo místico de Cristo. A famosa epístola "Duo sunt" do papa Gelásio I (492-496), dirigida ao imperador Anastácio, é, sem dúvida, a formulação teórica mais significativa da época para determinar uma concepção sobre a questão dos dois poderes definida nas expressões "auctoritas sacrata pontificum" e "regalis potestas", em que a primeira representa o princípio normativo e a segunda o poder executivo do que foi estabelecido pelo anterior.

Gelásio, na verdade, em boa parte de seus escritos, procurou enfatizar a noção de principatus apostolicae sedis e a ele se deve uma primeira básica clarificação sobre o conceito. ${ }^{99}$ Cristo-Melquisedec, que foi o último rex-sacerdos, transmitiu a Pedro a continuidade do sacerdotium que, na visão de Gelásio, deve orientar o poder real. A comissão petrina, assim como se encontra em Mt 16:18-19, desembocará no principatus da Igreja romana. seja do ponto de vista doutrinal assim como do jurídico: "Tu es Petrus et super hanc petram edificabo ecclesiam meam... et tibi dabo claves regni coelorum, et quodcumque ligaveris super terram, erit ligatum et in coelis, et quodcumque solveris super terram, erit solutum et in coelis". ${ }^{100}$ Daí a ênfase de Gelásio no Concílio de Roma (495): "Sedes apostólica, quae Christo domino delegante totius ecclesiae retinet principatum", no sentido de que todo o corpo dos cristãos tem o seu principatus na Igreja romana. ${ }^{101}$

Ullmann resumirá a doutrina gelasiana dizendo "que culmina na concepção monárquica do principatus: o papa, como sucessor de São Pedro, é o único a ter a auctoritas sobre o corpo universal dos cristãos, entre os quais o imperador tem efetivamente um lugar vital, mas de natureza auxiliar ou protetora, uma vez que sua função está reduzida à de um monarca com "secularis" ou "regia

${ }^{98}$ Leo I, Ep. 156 cap. 3-5, apud ULLMANN, op. cit., p. 13-14.

${ }^{99}$ A epistola publicada por A. Thiel, Epistulae Romanorum Pontificum genuinae I, Brunsbergae, 1868 , p. 350 sq., pode ser encontrada mais facilmente na obra mais recente de Conradus Kirch, Enchridion fontium historiae ecclesiasticae antiquae, Herder, 1960, p. 548-549.

${ }^{100}$ V. ULLMANN, W. Principios de gobierno y política em la Edad Media. Revista de Occidente. Madri, 1971, p. 37.

${ }^{101}$ ULLMANN, W. The government, op. cit., p. 15. 
potestas". ${ }^{102}$ Isidoro de Sevilha explicará que a Igreja é o "Corpus Jesu Christi" composto da multiplicidade das nações nas quais os príncipes exercem suas funções. Mas este "corpus" está moldado por uma única fé e, por conseguinte, ele se apresenta como um único "regnum", no sentido de ser uma congregação de todas as nações que constitui a Igreja de Cristo, assim como Isidoro o formula: "Huius populi congregatio ex gentibus ipsa est ecclesia". ${ }^{103}$ A definição de Isidoro antevê a futura societas christiana e a justificativa da adoção da "corona" ou do "regnum" e o uso da "purpura", em especial a partir do século XI, que não a diferenciaria dos antigos imperadores. Não é aqui, nos limites definidos deste nosso estudo, que trataremos do desenvolvimento e do seu rico significado simbólico que incorporou através do tempo e na Idade Média. Além da rotineira consagração, a cerimônia da coroação papal foi realizada como parte do ritual dos que se elevaram à cátedra de São Pedro no século seguinte. Ullmann indica que a modificação da mitra papal como corona ou regnum (phrigium) simbolizava esse processo, ${ }^{104}$ que o papa é caracterizado como "Qui sacerdos est regalis et imperialis episcopus, immo patriarcha et apostolicus". ${ }^{105}$ A afirmação de Kantorowicz, citada por Ullmann, confirma a convicção da "imperialization of the Church as one of the outstanding features of the Reform papacy". ${ }^{106}$

O significado da coroação papal, realizado em boa parte pelos papas do século XII, tinha a intenção de lembrar que o supremo poder monárquico pertencia ao vicarius Dei, uma vez que o poder real era apenas "temporal". Isso ainda será expresso, de modo inconteste, mais tarde, por Inocêncio III no Sermo in consecratione: "Solus autem Petrus assumptus est in plenitudinem postestatis. In signum spiritualium contulit mihi mitram, in signum temporalium dedit mihi coronam; mitram pro sacerdotio, coronam pro regno, illius me constituens, vicarium, qui habet in vestimento et in femore suo scriptum 'Rex regum et dominus dominantium, sacerdos in aeternum secundum ordinem Melchisedech". ${ }^{107}$

Recebido: 25/10/2010 - Aprovado: 31/05/2011.

\footnotetext{
${ }^{102}$ Idem, ibidem, p. 28.

${ }^{103}$ ULLMANN, The government, op. cit., p. 29.

${ }^{104}$ Idem, ibidem, p. 314-315, nas quais compara a redação das fontes da Donatio Constantini, Dictatus de Avranches e a do Dictatus de Gregorio VII. Esta última diz: "Solus [papa] uti possit imperialibus insigniis".

${ }^{105}$ Idem, ibidem, p. 316, nota 2, em que cita KLEWITZ, H. W. Die Entstehung des Kardinalscollegiums. In: Sav. Z., kan. Abt., xxvi (1936), p. 123, nota I.

${ }^{106}$ Idem, ibidem, p. 315 , nota 3 .

${ }^{107}$ Idem, ibidem, p. 317, nota 2, Sermo in consecratione, iii, MPL, ccxvii, 665.
} 